\title{
Parental Involvement and the Intergenerational Transmission of Economic Preferences, Attitudes and Personality Traits
}

Citation for published version (APA):

Zumbuehl, M., Dohmen, T., \& Pfann, G. (2021). Parental Involvement and the Intergenerational Transmission of Economic Preferences, Attitudes and Personality Traits. The Economic Journal, 131(638), 2642-2670. https://doi.org/10.1093/ej/ueaa141

Document status and date:

Published: 01/08/2021

DOI:

10.1093/ej/ueaa141

Document Version:

Publisher's PDF, also known as Version of record

Document license:

Taverne

Please check the document version of this publication:

- A submitted manuscript is the version of the article upon submission and before peer-review. There can be important differences between the submitted version and the official published version of record.

People interested in the research are advised to contact the author for the final version of the publication, or visit the DOI to the publisher's website.

- The final author version and the galley proof are versions of the publication after peer review.

- The final published version features the final layout of the paper including the volume, issue and page numbers.

Link to publication

\footnotetext{
General rights rights.

- You may freely distribute the URL identifying the publication in the public portal. please follow below link for the End User Agreement:

www.umlib.nl/taverne-license

Take down policy

If you believe that this document breaches copyright please contact us at:

repository@maastrichtuniversity.nl

providing details and we will investigate your claim.
}

Copyright and moral rights for the publications made accessible in the public portal are retained by the authors and/or other copyright owners and it is a condition of accessing publications that users recognise and abide by the legal requirements associated with these

- Users may download and print one copy of any publication from the public portal for the purpose of private study or research.

- You may not further distribute the material or use it for any profit-making activity or commercial gain

If the publication is distributed under the terms of Article 25fa of the Dutch Copyright Act, indicated by the "Taverne" license above, 


\title{
PARENTAL INVOLVEMENT AND THE INTERGENERATIONAL TRANSMISSION OF ECONOMIC PREFERENCES, ATTITUDES AND PERSONALITY TRAITS*
}

\author{
Maria Zumbuehl, Thomas Dohmen and Gerard Pfann
}

\begin{abstract}
We empirically investigate the link between parental involvement and shaping of the economic preferences, attitudes and personality traits of their children. We exploit information on the risk and trust attitudes, the Big Five personality traits and locus of control of parents and their children, as well as rich information about parental efforts in the upbringing of their children from the German Socio-Economic Panel Study (SOEP). Our results show that parents who are more involved in the upbringing of their children have children with more favourable attitudes and traits. These children rank higher in traits that further their success in life, and they are more similar to their parents in those attitudes, where the optimum level is more ambiguous.
\end{abstract}

Mounting evidence in the economics, psychology and sociology literature indicates that preferences, attitudes and personality traits are transmitted from parents to children. ${ }^{1}$ Dohmen et al. (2012) document an intergenerational correlation in risk and trust attitudes, while Duncan et al. (2005) show that personality traits are transmitted from parents to their children. This intergenerational transmission arguably contributes to the intergenerational correlation in economic outcomes such as income, education, or health that has been well documented in the literature (for reviews see, e.g., Björklund and Salvanes, 2011; Black and Devereux, 2011; Holmlund et al., 2011; Lindahl et al., 2016). ${ }^{2}$ As social mobility is of prime interest for society, social scientists need to better understand the channels through which these facets of human personality are transmitted from parents to children. How preferences are formed and whether they can be moulded by nurture is of particular concern for policymakers. ${ }^{3}$ Despite some recent evidence

\footnotetext{
* Corresponding author: Thomas Dohmen, Institute for Applied Microeconomics, University of Bonn, Maastricht University, IZA, DIW and CESifo, Germany. Email: t.dohmen@uni-bonn.de
}

This paper was received on 6 June 2018 and accepted on 22 December 2020. The Editor was Frederic Vermeulen.

The data and codes for this article are available on the Journal website. They were checked for their ability to reproduce the results presented in the article. The authors were granted an exemption to publish parts of their data because access to these data is restricted. However, the authors provided the Journal with temporary access to the data, which enabled the Journal to run their codes. The codes for the parts subject to exemption are also available on the Journal website. The restricted access data and these codes were also checked for their ability to reproduce the results presented in the article.

We thank Fabrizio Zilibotti, Arjan Non, Lex Borghans, Nicolas Salamanca, as well as the members of the IAME retreat at the University of Bonn for their helpful comments and suggestions. Thomas Dohmen gratefully acknowledges funding from the Deutsche Forschungsgemeinschaft (DFG, German Research Foundation) through CRC TR 224 (Project A01) and under Germany's Excellence Strategy_EXC 2126/1-390838866. Maria Zumbuehl gratefully acknowledges funding by the Swiss State Secretariat for Education, Research and Innovation SERI through the Leading House grant 1315000881. Gerard Pfann gratefully acknowledges the hospitality of SOFI at Stockholm University.

${ }^{1}$ Psychologists and sociologist have been studying the transmission of personality traits from parents to children since the 1930s (Loehlin, 2005), in economics the interest in the topic is more recent (e.g., Anger, 2012 and Grönqvist et al., 2017).

2 Bowles and Gintis (2002), for example, investigate how the transmission of personality traits, as well as IQ and race, influences intergenerational mobility in socioeconomic status.

3 There is evidence that both nature and nurture play a role in preference transmission. Cesarini et al. (2009) show that there is a genetic effect on preferences, while Dohmen et al. (2012) point out the importance of socialisation in the intergenerational transmission of preferences. 
(see Kosse et al., 2020, Falk et al., 2021 or Heckman et al., 2017 for socialisation in general and Alan et al., 2017 and Brenøe and Epper, 2019 for socialisation by parents), little is known about the channels through which socialisation affects preference formation.

A common central assumption in theories of cultural transmission (e.g., Bisin and Verdier, 2001; Doepke and Zilibotti, 2008), is that parents and the social environment affect the transmission of culture, values, attitudes and preferences. These models differ in their assumptions about parental motives that shape the transmission process. Bisin and Verdier (2001), for example, assume that imperfect empathy prevails among parents, i.e., that parents are altruistic towards their children but postulate that children's evaluation of choices resembles their own subjective evaluation, which is determined by their own utility function. Hence, parents cannot 'perfectly empathise' with their children and evaluate their children's choices only through the lens of their own utility function. As a result, they are inclined to inculcate their own values, attitudes and preferences in children, which leads to similarity in these facets of personality between parents and their children. Different from assuming imperfect empathy, Doepke and Zilibotti (2017) assume that parents are driven by a combination of concern for the well-being of the child (i.e., altruism) and a paternalistic motive. These parents try to mould their children's preferences to increase the children's life-time welfare. They are prepared to incur costs and trade-off their children's felicity during childhood for higher utility as adults. Instilling preferences and traits that foster success, e.g., that are conducive to human capital accumulation, does not necessarily imply that parents want their children to have preferences and traits that are similar to their own, especially if their own preferences do not foster success in life. Such traits include, for example, conscientiousness and an internal locus of control.

We assess empirically the role of parents in the transmission of preferences and traits, by studying whether and how children's attitudes and personality traits are shaped by parental involvement. We thereby make two contributions to the literature. First, since our results indicate that increased parental involvement strengthens the preference transmission, we document empirically that there is a mechanism through which children's preferences can be moulded by parents. We thereby also provide evidence that supports a key assumption of Doepke and Zilibotti (2017), namely that parents can mould their children's preferences. ${ }^{4}$ Second, we document that parental involvement increases similarity between parents and children for preferences and traits for which a stronger preference or a higher level of a trait is not unambiguously favorable. This is, for example, the case for risk and trust attitudes, as circumstances, economic conditions and the social environment determine how these attitudes affect life success.

We measure parental involvement by combining proxies about the frequency and intensity of parental engagement in their offspring's life during childhood and adolescence. These proxies capture aspects such as talking about the child's life and worries, but also the degree of parental involvement in their children's educational development.

In our empirical analysis, we focus on risk and trust attitudes, as well as on the Big Five personality traits and locus of control, all of which have been shown to play an important role in decision-making. Risk attitudes have an impact not only on financial decision-making but also on other realms of a person's life, such as choice of education, occupation as well as health outcomes (Dohmen et al., 2011). Trust has been shown to be conducive to the development of impersonal markets and the well-functioning of political systems (see, e.g., Guiso et al., 2008). Personality

\footnotetext{
${ }^{4}$ However, our data do not allow us to test whether parents follow an optimal parenting strategy, because, firstly, we lack data on parental intentions and their utility functions, and secondly, we do not observe the costs and returns of moulding preferences.
} 
traits, in particular conscientiousness, openness to experience and internal locus of control, are linked positively to life outcomes, such as educational attainment and economic success (see, e.g., Bowles et al., 2001, Almlund et al., 2011, or Becker et al., 2012).

Using data from the German Socio-Economic Panel Study (SOEP) we find that parents who are more involved in the upbringing of their children are more similar to their adult children in willingness to take risk and in trust towards strangers. We also find that parents who are more involved in the upbringing of their kids have children who are more conscientious and have a stronger internal locus of control. This is in line with the assumption in Doepke and Zilibotti (2017) that parents maximise an objective function that combines altruism and paternalism towards children.

We start by investigating the transmission of the parents' own preferences on the basis of risk and trust attitudes, and extend the array of preferences and traits to personality traits, in order to further investigate the option of targeted moulding of traits. This also allows us to test for interaction effects between parents' traits and their efforts. Having established the existence of a significant correlation between parental involvement and the formation of preferences and personality, we exploit the panel structure of our data set and provide additional evidence from the TwinLife data set, a SOEP related study, in order to shed light on the causal nature of this relationship.

The remainder of this article is structured as follows. Section 1 introduces our data and explains the choice of the main variables. Section 2 introduces the model, discusses the main results, measurement error and causality issues. Section 3 concludes the article.

\section{Data}

Our analysis uses data from the German SOEP, ${ }^{5}$ which not only provides information about economic attitudes and parental involvement, but also allows us to link grown up children to their parents. (We hereafter refer to these young adults who are our main observations as children, according to their position in the family.) The SOEP is a large representative household survey that has been conducted annually since $1984 .{ }^{6}$ Once sampled in the SOEP, each individual is followed, even after leaving the initially sampled household. This feature is especially important for our study since it allows us to observe also young adults and their parents who no longer live in the same household.

An important source of information for our article is the youth biography questionnaire that is requested of every newly entering young individual since 2000. This questionnaire is administered to young people who live in an SOEP household and have just become old enough (turning 18 in the following year) to enter the regular personal survey in the next year. Aside from background questions, such as personal education history, the respondents to the youth survey are asked detailed questions about their upbringing and their interaction and relationship with their parents. In addition, a set of economic attitudes and personality traits are elicited subsequently in the regular SOEP questionnaires that are administered after age 17. If the individual answered the question to a certain attitude in several subsequent waves, we consider the first of those waves. The information on the attitudes of the parents is taken from the same wave as that of the child's attitudes. Every observation thus consists of a child-mother-father triplet. For risk attitudes we

\footnotetext{
5 Socio-Economic Panel (SOEP), data for years 1984-2015, version 32, SOEP, 2015, doi:10.5684/soep.v32.

${ }^{6}$ Schupp and Wagner (2002), Wagner et al. (2007) and Wagner et al. (2008) give detailed information on the construction and maintenance of the SOEP.
} 

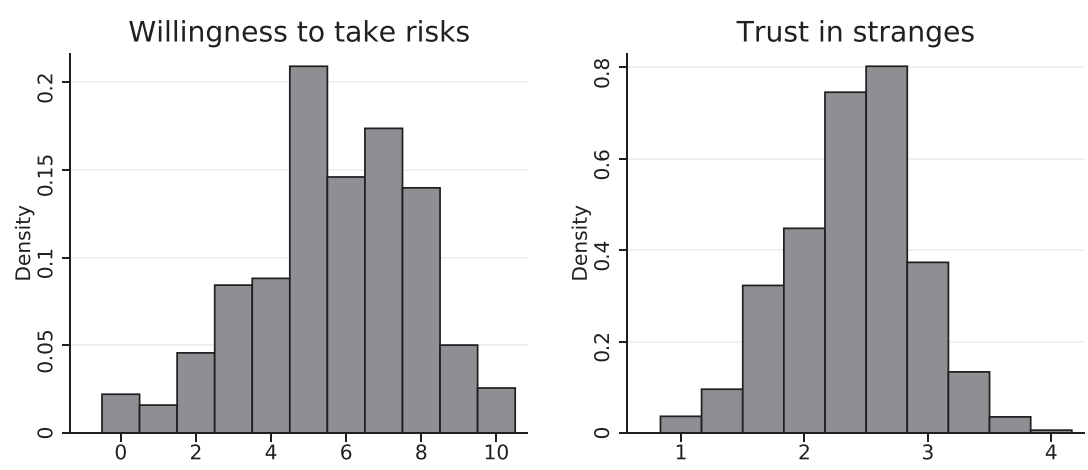

Fig. 1. Preferences and Attitudes.

Notes: The histograms display the distribution risk and trust attitudes among the children in our sample (when they first answer the respective questions).

Data source: SOEP, v32.

have a sample of 3,393 observations. Since the trust questions were asked only three times (compared to nine waves containing the risk questions), the trust sample has 2,119 observed parent-child triplets. The sample sizes for personality traits range from 1,915 to $2,274 .^{7}$ The personality traits have been elicited at the same time, but the sample differ per trait due to item non-response.

\subsection{Preference and Personality Measures}

This section describes how we construct our dependent variable and measure the underlying attitudes.

\subsubsection{Risk}

Individuals' risk attitudes are assessed based on a survey question asking the parents and children in our sample how willing they are to take risks in general. The answer categories range from zero, which denotes not willing to take risks at all, to ten, which stands for very willing to take risks. The left panel of Figure 1 shows the distribution of answers in our sample of young adults. The survey question is experimentally validated in the study by Dohmen et al. (2011), which also documents that the answer to the general risk question is a good predictor for a number of risky decisions. The general risk question was asked in ten waves: in 2004, 2006 and yearly since 2008.

\subsubsection{Trust}

The measure of trust attitudes is slightly more complex as it combines three survey questions into an aggregated trust index. In 2003, 2008 and 2014 the respondents of the main SOEP survey were asked how strongly they agreed with the following three statements on a scale from 1 to 4, where 1 means 'Agree completely' and 4 means 'Disagree completely': 'On the whole one can trust people', 'Nowadays one can't rely on anyone', and 'If one is dealing with strangers, it

\footnotetext{
7 The sample sizes are: Big Five openness (1,919), Big Five conscientiousness (1,915), Big Five extraversion $(1,918)$, Big Five agreeableness $(1,926)$, Big Five neuroticism $(1,924)$ and locus of control $(2,274)$.
}

(C) 2021 Royal Economic Society. 

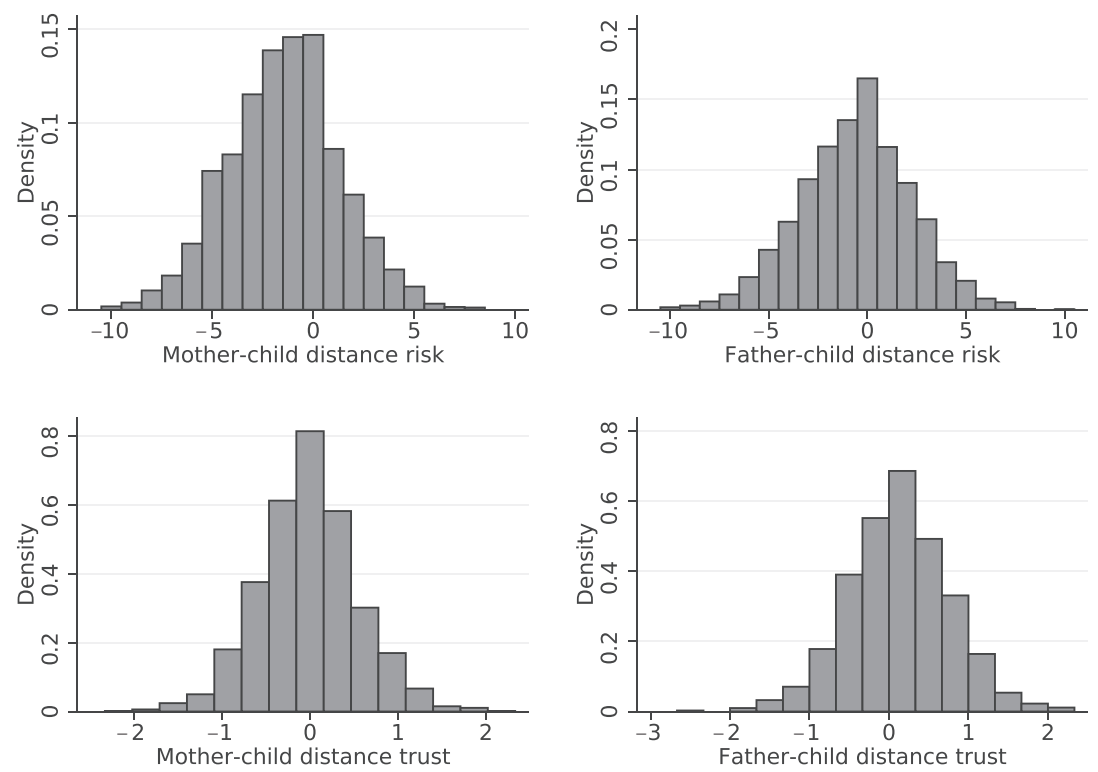

Fig. 2. Difference Between Parent's and Child's Attitudes.

Notes: Distribution of the difference in attitude between parent and child (parent's attitude minus child's attitude).

Own calibration; data source: SOEP, v32.

is better to be careful before one can trust them', We use a simple average over the three trust measures as our trust index. ${ }^{8}$ The right panel of Figure 1 shows the distribution of the trust index for our sample of young adults. Fehr et al. (2002) validate this trust measure by showing that trust in strangers, measured by the three above-mentioned questions, indeed predicts first mover behaviour in a trust game.

\subsubsection{Similarity in preferences}

Figure 2 displays the differences between parents' and children's risk and trust attitudes. Since we conjecture that parents want to transmit their own attitudes in the domains of risk taking and trust to their children, we posit that a higher degree of similarity of parents' and their child's attitude indicates stronger transmission.

We construct four different similarity measures that serve as dependent variables in the first part of our analysis that investigates similarity: the difference in risk attitudes between mother and child $\left(\Delta_{R}^{M C}\right)$ and between father and child $\left(\Delta_{R}^{F C}\right)$ and the difference in trust attitudes between mother and child $\left(\Delta_{T}^{M C}\right)$ and between father and child $\left(\Delta_{T}^{F C}\right)$. We calculate each difference measure as the absolute difference between the child's and parent's attitude. The average difference in risk attitudes between mothers and their children is 2.46 with a standard deviation of 1.95 , while that between fathers and their children is 2.24 , with a standard deviation of 1.84 . In trust attitudes, mothers and their children differ, on average, by 0.46 points on the trust index, with a

\footnotetext{
${ }^{8}$ We reversed the answers of the first question so that a higher number on the trust index indicates a higher level of trust.
}

(C) 2021 Royal Economic Society. 
standard deviation of 0.40 , while fathers differ by 0.49 points from their children, with a standard deviation of 0.42 . In our analysis, we standardise each difference measure.

In our main model, we use current measures of attitude, without controlling for the effect of age on attitudes. We do this for two reasons. First, we assume that the parents want to transmit their current attitudes, rather than the attitudes they had when they were of the same age as their children are now. Second, if children use their parents as role models, they can only observe the parents' current attitudes. However, later we demonstrate as a robustness check that this age-induced difference in attitudes is not driving our results.

\subsubsection{Personality traits and locus of control}

The SOEP contains various measures that pertain to personality, most importantly measures of locus of control and the Big Five personality traits. We focus on these measures, as evidence shows that the underlying constructs relate to economic outcomes (Bowles et al., 2001; Almlund et al., 2011; Becker et al., 2012). SOEP respondents answered questions designed to measure locus of control in the 2005, the 2010 and the 2015 wave of the survey. We construct a measure of internal locus of control as the first principal component of answers to seven questions (following Specht et al., 2013). Individuals with a higher score have a stronger sense of being able to shape their own environment.

The Big Five consist of the personality traits openness, conscientiousness, extraversion, agreeableness and neuroticism. The Big Five in the SOEP survey are assessed using the BFI-S psychology questionnaire, a 15-item subset of the NEO-FFI version (see Gerlitz and Schupp, 2005). For each trait there are three items in the survey, for which individuals indicate on a seven-point scale to what extent they agree with the statement. Averaging over the three responses yields the score for the particular trait. The Big Five personality traits questions were asked in 2005, 2009 and 2013. Figure 3 shows the distribution of the personality traits among our sample of children.

\subsection{Parental Involvement}

We are interested in whether parental involvement, broadly defined, relate to the transmission of economic preferences, attitudes and traits. We focus on measures of parental effort in the upbringing of children. ${ }^{9}$ This includes, on the one hand, how much parents are involved in their children's school situation, which is an important part of a child's daily life, and on the other hand, how much the parent participates in the child's life, and how much the parent involves the child in family matters. ${ }^{10}$

We consider general parental involvement for two reasons. First, parental involvement can be seen as a type of general investment, that parents could choose to engage in if they wanted. ${ }^{11}$

\footnotetext{
9 The importance of parental effort or involvement in intergenerational transmission has been demonstrated in the transmission of economic outcomes. In an investigation of the driving forces of sibling correlations in long-run income, Björklund et al. (2010) find that parental investments and parenting practices have strong predictive power in explaining sibling correlations.

10 The measures for parental participation in a child's life and how much the parent involves the child in decisionmaking are taken from a nine item scale for supportive parenting (see Weinhardt and Schupp, 2011 for more information on the supportive parenting scale and it's application in the SOEP). We use seven out of the nine items, excluding two items which might be reversely related with our dependent variable. The two omitted items are: 'The parent shows that she/he loves you', and 'The parent gives you the impression that she/he really trusts you'.

${ }^{11}$ Such investments would not be directed but rather general investments. There is no very specific and easily observable parental investment we can link directly to the transmission of both risk and trust attitudes, like it is possible for the research on the transmission of particular cultural traits or religion (for example Patacchini and Zenou, 2016 

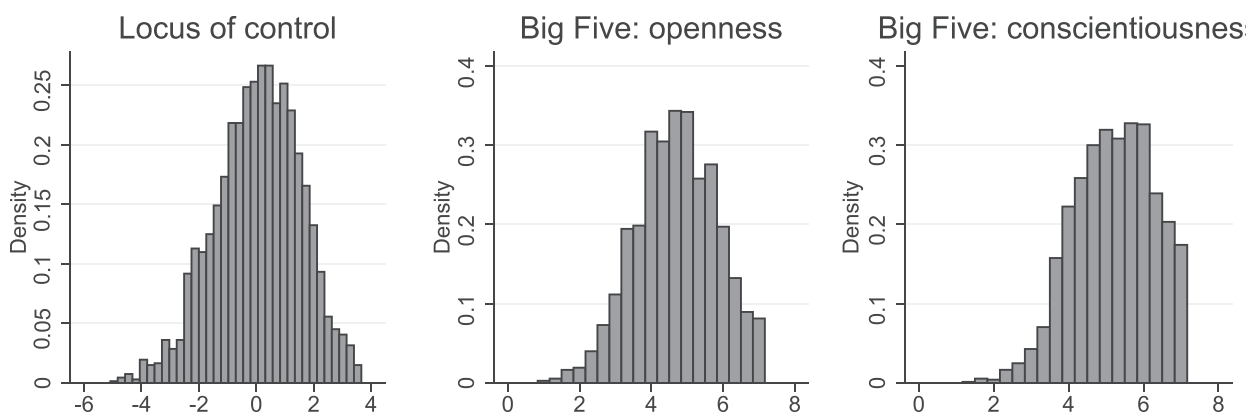

Big Five: extraversion
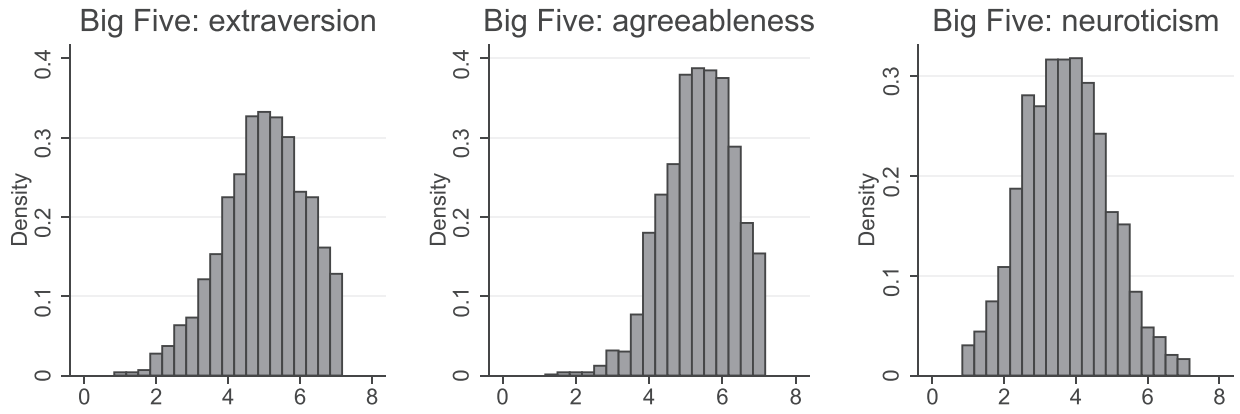

Fig. 3. Personality Traits.

Notes: The histograms display the distribution of locus of control and the Big Five personality traits among the children in our sample (when they first answer the respective questions).

Data source: SOEP, v32.

Second, the growing literature on parenting style points out the importance and potential scope of parental behaviour on the formation of children's non-cognitive skills. ${ }^{12}$ A complementary approach would be to focus on time investments of parents. However, this approach has its own shortcomings. Firstly, a pure quantitative measure neglects the quality of the time spent. ${ }^{13}$ Secondly, this approach requires us to aggregate the time spent throughout the childhood into a meaningful measure. The aggregation would ideally weigh investments in sensitive periods of the child's life more and adjust for the timing and sequence of investments (Cunha and Heckman, 2007).

\subsubsection{Involvement proxies}

The youth questionnaire of the SOEP provides proxies for the type of parental involvement that we are investigating. We can measure how involved parents are in their children's school situation, how much parents participate in the life of their children, and how strongly they integrate their children in decision processes. Table 1 lists the proxies we use in our study, with means and standard deviations for both (risk and trust) samples. All the proxies are measured either as binary

investigate the transmission of religiousness by using the frequency of taking children to religious services as a measure of involvement).

12 See Heckman et al. (2013) for the importance of early childhood environment more generally.

13 Since the range of possible interaction opportunities, as well as the level of (mental) engagement in them is wide, a simple quantitative time measure would not capture the intensity of involvement. Further, if a family has more than one child, it is hard to capture exactly how much the time is spent with one specific child. 


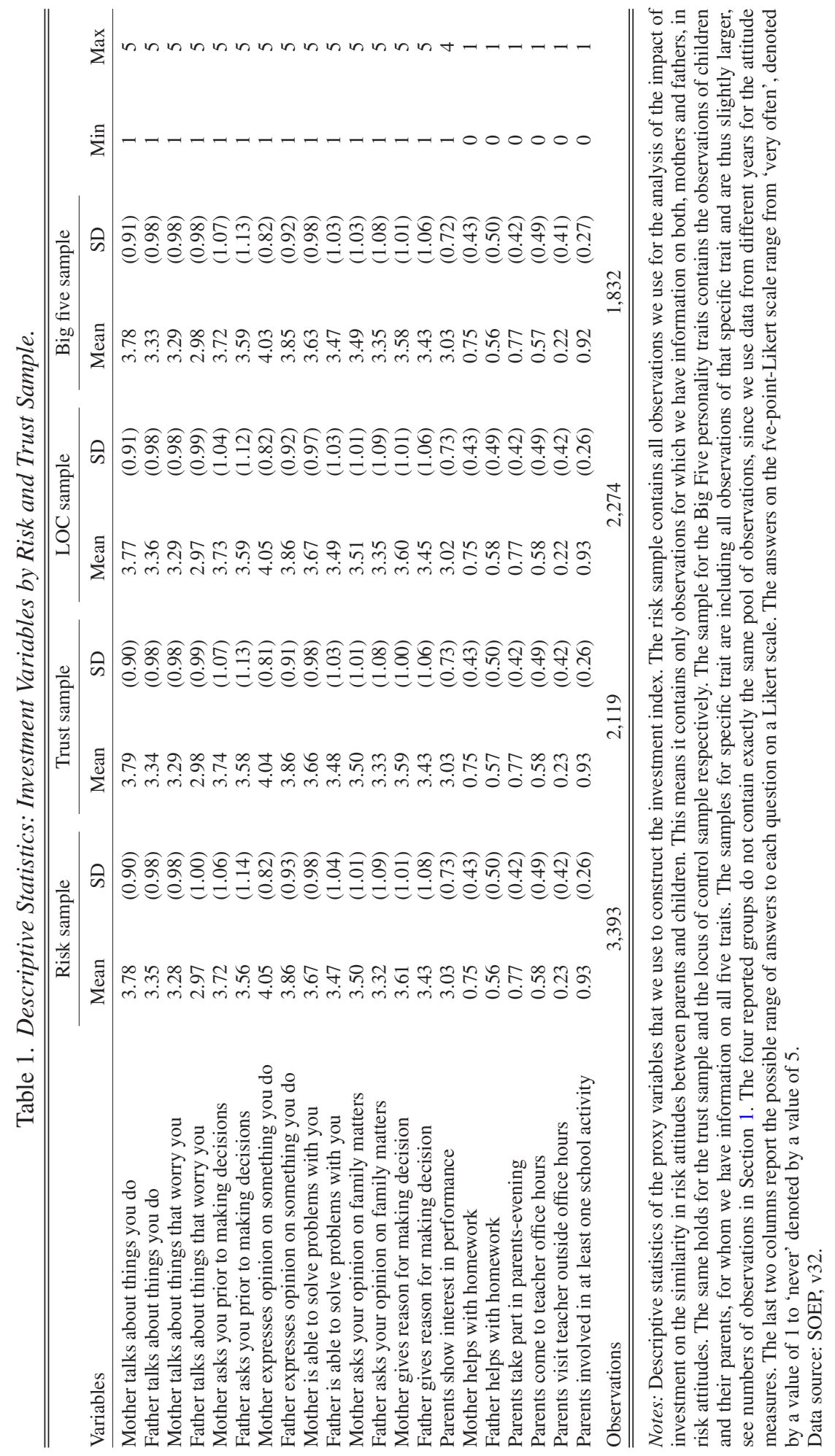


Table 2. Descriptive Statistics by Parental Involvement.

\begin{tabular}{|c|c|c|c|c|c|}
\hline \multirow[b]{3}{*}{ No. of kids in family } & \multicolumn{4}{|c|}{ Mother } & \multirow{3}{*}{$\frac{p \text {-value } \Delta}{0.000}$} \\
\hline & \multicolumn{2}{|c|}{ High involvement } & \multicolumn{2}{|c|}{ Low involvement } & \\
\hline & 2.64 & $(1.16)$ & 2.83 & $(1.34)$ & \\
\hline Age & 18.17 & $(1.07)$ & 18.22 & $(1.14)$ & 0.226 \\
\hline 1 if female & 0.52 & $(0.50)$ & 0.46 & $(0.50)$ & 0.001 \\
\hline Mother years of education & 12.61 & $(2.70)$ & 11.94 & $(2.54)$ & 0.000 \\
\hline Father years of education & 12.82 & $(2.84)$ & 12.29 & $(2.81)$ & 0.000 \\
\hline 1 if no migration background & 0.79 & $(0.41)$ & 0.74 & $(0.44)$ & 0.000 \\
\hline HH-income vigintile & 11.36 & $(5.43)$ & 10.40 & $(5.34)$ & 0.000 \\
\hline Age difference MC & 28.24 & (4.94) & 27.95 & $(5.13)$ & 0.098 \\
\hline Age difference FC & 30.99 & $(5.76)$ & 30.83 & $(5.94)$ & 0.434 \\
\hline 1 if $\Delta_{R}^{M F}>$ median & 0.37 & $(0.48)$ & 0.39 & $(0.49)$ & 0.238 \\
\hline \multirow[t]{3}{*}{ Observations } & 1,778 & & 1,615 & & \\
\hline & \multicolumn{4}{|c|}{ Father } & \\
\hline & \multicolumn{2}{|c|}{ High involvement } & \multicolumn{2}{|c|}{ Low involvement } & $p$-value $\triangle$ \\
\hline No. of kids in family & 2.63 & $(1.20)$ & 2.84 & $(1.31)$ & 0.000 \\
\hline Age & 18.19 & $(1.08)$ & 18.21 & $(1.14)$ & 0.522 \\
\hline 1 if female & 0.50 & $(0.50)$ & 0.49 & $(0.50)$ & 0.403 \\
\hline Mother years of education & 12.59 & $(2.70)$ & 11.93 & $(2.53)$ & 0.000 \\
\hline Father years of education & 12.95 & $(2.87)$ & 12.12 & $(2.74)$ & 0.000 \\
\hline 1 if no migration background & 0.80 & $(0.40)$ & 0.73 & $(0.45)$ & 0.000 \\
\hline $\mathrm{HH}$-income vigintile & 11.54 & $(5.38)$ & 10.15 & $(5.33)$ & 0.000 \\
\hline Age difference MC & 28.36 & $(4.92)$ & 27.80 & $(5.15)$ & 0.001 \\
\hline Age difference FC & 31.14 & $(5.70)$ & 30.63 & $(6.01)$ & 0.011 \\
\hline 1 if $\Delta_{R}^{M F}>$ median & 0.36 & $(0.48)$ & 0.40 & $(0.49)$ & 0.007 \\
\hline Observations & 1,837 & & 1,556 & & \\
\hline
\end{tabular}

Notes: Descriptive statistics on the control variables, split by parental involvement (high and low). If no parent is mentioned, the variables refer to the child's characteristics. We use the sample of our analysis on risk for this summary table. ' $p$-value $\Delta^{\prime}$ ' reports the $p$-value of a mean-comparison test between the sample of children with high and low involved parents.

Data source: SOEP, v32.

variables or on a 4- or 5-point scale, as described in the last two columns of Table 1. Most of the school-related proxies are measured on an aggregate level for both parents together, while for the other proxies we can distinguish between the efforts of mothers and fathers. Together, these 13 proxies provide insight into the general involvement of parents in their children's upbringing. However, there are many more possible ways of parental involvement that we cannot address in this study, such as, e.g., joint leisure activities. We assume that all the proxy variables measure parental involvement, but none of them measure it perfectly. We combine the proxies in an index to measure the underlying true parental involvement. Using principal component analysis on the respective 13 proxies allows us to construct such an involvement index for mothers and fathers (we take the first factor to be the involvement index, Table A1 in the Appendix displays the factor loadings).

Parents who invest much in their children, as measured by our involvement proxy, differ from parents who invest little in the upbringing of their children. Table 2 displays the means and standard deviations of background characteristics for the groups of high and low investing mothers and fathers. We find that parents who invest more in the upbringing of their children are on average more educated, earn more and are older than parents who invest less. 


\section{Results}

Next, we analyse the relationship between the effort parents put into the upbringing of their children and their influence on the formation of the children's preferences. We begin by establishing the link between parental involvement and the formation of the children's attitudes. We start with risk and trust attitudes and then extend the analysis to personality traits. This first part of the results section documents the correlation, without any claim to causality. In the second part of the section we then address the question of causality.

\subsection{Parental Involvement and the Transmission of Risk and Trust Attitudes}

\subsubsection{Main results}

Findings by Dohmen et al. (2012) and recent evidence by Kosse et al. (2020) highlight the role of the social environment for the development of economic preferences and prosociality. As parental behaviour is a key facet of the social environment during childhood and adolescence, it is natural to investigate the role of parents for preference formation. We show that parental involvement is related to the transmission of own risk and trust attitudes to children. In particular, we investigate the similarity of children to their parents. In the next step we will, however, also consider the option that parental involvement can have a direct impact on the level of the child's attitude, independent of the parents' attitudes.

Table 3 reports the results of regressing the similarity in risk and trust attitudes on parental involvement and background characteristics, for mother and child or father and child respectively. We find a negative relation between the involvement and the difference in attitude between parents and their children in all four cases; however, in the second case (risk attitudes father-child) the relation is not statistically significant. ${ }^{14}$ In other words, we find that parents who are more involved in the upbringing of their children have children who are more similar to them with respect to their willingness to take risks and with respect to trust in strangers. One standard deviation increase in the involvement by the mother, for example, is related to a decrease in the absolute difference in risk attitudes between mother and child of 0.061 standard deviations. These findings support the theoretical models on the transmission of attitudes (Bisin and Verdier, 2001; Doepke and Zilibotti, 2017) that assume that parents can influence the preferences and attitudes of their children.

Table 2 shows that parents who are highly involved in the upbringing of their children differ from less involved parents in many aspects. For our main analysis we thus control for an array of potentially important background variables. ${ }^{15}$ We control for the socio-economic background of the family by including the level of education of both parents as well as the level of household income per capita in the year when the child filled out the youth questionnaire (to make the income measure comparable across years we compute households' placement in the income distribution of the actual SOEP wave, in 20-quantiles). Family size is another important variable in our analysis, since it can influence the formation of preferences and attitudes not only through available financial resources per child and potential environment effects of siblings, but also

\footnotetext{
14 If we only take involvement that pertains to parenting style into account, we find very similar results. The involvement in schooling is largely insignificant on the transmission of attitudes. This is not unexpected, however, since involvement in schooling is in part also driven by the child's needs. The results with different involvement measures (only parenting, only school, or only a single item of parenting) can be found in the supplementary material

${ }_{15}$ Table A2 in the Appendix provides the results of the main regressions without control variables. The coefficient estimates for parental involvement remain quantitatively very similar.
} 
Table 3. PCA: The Impact of Parental Involvement on Differences in Risk and Trust.

\begin{tabular}{|c|c|c|c|c|}
\hline & \multicolumn{4}{|c|}{ Dependent variables: } \\
\hline & \multicolumn{2}{|c|}{ Risk } & \multicolumn{2}{|c|}{ Trust } \\
\hline & $\begin{array}{c}\text { Mothers } \\
\Delta_{R}^{M C}\end{array}$ & $\begin{array}{c}\text { Fathers } \\
\Delta_{R}^{F C}\end{array}$ & $\begin{array}{c}\text { Mothers } \\
\Delta_{T}^{M C}\end{array}$ & $\begin{array}{c}\text { Fathers } \\
\Delta_{T}^{F C}\end{array}$ \\
\hline Maternal involvement (PCA) & $\begin{array}{c}-0.064^{* * *} \\
(0.019)\end{array}$ & & $\begin{array}{c}-0.047^{* *} \\
(0.023)\end{array}$ & \\
\hline Paternal involvement (PCA) & & $\begin{array}{r}-0.029 \\
(0.021)\end{array}$ & & $\begin{array}{c}-0.062^{* *} \\
(0.029)\end{array}$ \\
\hline No. of kids in family & $\begin{array}{r}-0.001 \\
(0.017)\end{array}$ & $\begin{array}{r}-0.001 \\
(0.015)\end{array}$ & $\begin{array}{r}-0.030^{*} \\
(0.018)\end{array}$ & $\begin{array}{c}-0.045^{\text {*** }} \\
(0.016)\end{array}$ \\
\hline Age & $\begin{array}{c}0.012 \\
(0.016)\end{array}$ & $\begin{array}{c}0.006 \\
(0.018)\end{array}$ & $\begin{array}{r}-0.006 \\
(0.015)\end{array}$ & $\begin{array}{c}-0.002 \\
(0.016)\end{array}$ \\
\hline 1 if female & $\begin{array}{c}-0.159^{* * *} \\
(0.033)\end{array}$ & $\begin{array}{c}-0.043 \\
(0.034)\end{array}$ & $\begin{array}{c}0.007 \\
(0.043)\end{array}$ & $\begin{array}{c}0.032 \\
(0.042)\end{array}$ \\
\hline Mother years of education & $\begin{array}{r}-0.007 \\
(0.009)\end{array}$ & $\begin{array}{c}0.002 \\
(0.008)\end{array}$ & $\begin{array}{c}0.005 \\
(0.011)\end{array}$ & $\begin{array}{c}0.016 \\
(0.011)\end{array}$ \\
\hline Father years of education & $\begin{array}{c}-0.004 \\
(0.008)\end{array}$ & $\begin{array}{c}-0.005 \\
(0.008)\end{array}$ & $\begin{array}{r}-0.007 \\
(0.010)\end{array}$ & $\begin{array}{r}-0.010 \\
(0.011)\end{array}$ \\
\hline 1 if no migration background & $\begin{array}{c}-0.123^{* * *} \\
(0.044)\end{array}$ & $\begin{array}{c}-0.143^{* * *} \\
(0.049)\end{array}$ & $\begin{array}{c}0.068 \\
(0.055)\end{array}$ & $\begin{array}{c}-0.072 \\
(0.058)\end{array}$ \\
\hline $\mathrm{HH}$-income vigintile & $\begin{array}{c}-0.001 \\
(0.004)\end{array}$ & $\begin{array}{c}-0.004 \\
(0.004)\end{array}$ & $\begin{array}{c}-0.005 \\
(0.005)\end{array}$ & $\begin{array}{r}-0.002 \\
(0.005)\end{array}$ \\
\hline Age difference $\mathrm{MC}$ & $\begin{array}{r}-0.008^{*} \\
(0.005)\end{array}$ & $\begin{array}{c}0.000 \\
(0.005)\end{array}$ & $\begin{array}{r}-0.000 \\
(0.006)\end{array}$ & $\begin{array}{c}0.005 \\
(0.007)\end{array}$ \\
\hline Age difference FC & $\begin{array}{c}0.007^{*} \\
(0.004)\end{array}$ & $\begin{array}{c}0.005 \\
(0.005)\end{array}$ & $\begin{array}{l}0.006 \\
(0.006)\end{array}$ & $\begin{array}{r}-0.000 \\
(0.006)\end{array}$ \\
\hline 1 if $\Delta_{R}^{M F}>$ median & $\begin{array}{l}0.418^{* * *} \\
(0.038)\end{array}$ & $\begin{array}{l}0.192^{* * *} \\
(0.038)\end{array}$ & & \\
\hline 1 if $\Delta_{T}^{M F}>$ median & & & $\begin{array}{l}0.326^{* * *} \\
(0.047)\end{array}$ & $\begin{array}{l}0.501^{* * *} \\
(0.049)\end{array}$ \\
\hline Constant & $\begin{array}{r}-0.072 \\
(0.338)\end{array}$ & $\begin{array}{r}-0.183 \\
(0.358)\end{array}$ & $\begin{array}{r}-0.140 \\
(0.321)\end{array}$ & $\begin{array}{c}-0.121 \\
(0.338)\end{array}$ \\
\hline $\begin{array}{l}\text { Observations } \\
R^{2}\end{array}$ & $\begin{array}{l}3,393 \\
0.064\end{array}$ & $\begin{array}{l}3,393 \\
0.024\end{array}$ & $\begin{array}{l}2,119 \\
0.032\end{array}$ & $\begin{array}{l}2,119 \\
0.069\end{array}$ \\
\hline
\end{tabular}

Notes: OLS estimates, the dependent variables are the standardised difference in risk attitudes between mother/father and child in Columns (1)/(2) and in trust attitudes between mothers/father and child in Columns (3)/(4). Risk and trust attitudes are measured in survey questions, explained in Subsection 1.1. The variables of interest, 'Maternal involvement (PCA)' and 'Paternal involvement (PCA)', are indices, each constructed through factor analysis on 13 involvement proxies. We use the first factor as final involvement index. The variable ' 1 if $\Delta_{R}^{M F}>$ median' is a binary variable that indicates parents that are heterogeneous in their risk attitudes, and ' 1 if $\Delta_{R}^{M F}>$ median' analogously for trust. In addition to the listed variables we also control for the year of the attitudes elicitation. Robust standard errors in parentheses allow for clustering at the parent level; * significant at $10 \%$; ** significant at $5 \%$; *** significant at $1 \%$.

through the amount of time available to the parents for every single child in the family (Table 2 provides some evidence that parents with more children do on average invest less in every single child). We control for age differences between the child and both parents. ${ }^{16}$

The literature on the intergenerational transmission of culture (e.g., Bisin and Verdier, 2001) shows that under certain assumptions minorities have bigger incentives to invest in their children. We thus include a variable that captures whether the child has a migration background (both direct migration and migration of parents) to control for possible effects of being a member of an ethnic minority. We also include a measure of how heterogeneous the parents are with respect to

16 Table A3 in the Appendix shows the coefficients for parental involvement when the attitude variables are adjusted for the age of the respondent. The results stay qualitatively the same. 
the attitude in question. Finally, we also control for the age of the child at the time of the attitude elicitation, the gender of the child and the year in which the attitude was elicited.

Conditional on parents' involvement, we find little effects of family background on the transmission of attitudes, and also personal characteristics of the child are mostly insignificant. Having a migration background is related to weaker transmission of risk attitudes. Finally, the coefficient for the binary variable that indicates heterogeneous parents is both large and statistically significant. This is not surprising: if the parents' attitudes are far apart from each other, the child's attitude mechanically has to be far apart from at least one parent, or equally far away from both if the child is in the middle. In the risk sample, parents are classified as heterogeneous if they are separated by three or more points on the 11-point Likert scale for the general risk question. The average distance among heterogeneous parents is 4.2 points.

One could conjecture that the relation between parental involvement and the transmission is not linear and homogeneous across different demographic groups. For example, the transmission might be stronger for same-sex parent-child couples (mother-daughter or father-son). Likewise, the same level of parental involvement might have a stronger effect on transmission for more educated parents. Further, the effect of involvement might be weaker the more dissimilar the preferences of the parents are, because each parent might want to influence the child in a different direction. Finally, the returns to involvement might depend on the level of involvement, or on the direction of the intended change of preference (e.g., it might be easier to reduce risk aversion than to increase it). We therefore assess whether transmission depends on gender of parents and children, parental education, degree of diversity of parents' preferences and nonlinearities in returns to involvements.

In Table 4 we show that parental and child characteristics as well as nonlinearities and asymmetries of the effect of parental involvement do not play a major role. While we find similar coefficients on the relationship between parental involvement and similarity in attitudes and preferences to those reported in Table 3, this relationship does not depend on the gender-match of parents and children. This is evident from the insignificant coefficient on the interaction term between the gender of the child and parental involvement in each column of Panel 1, which are based on the same regression as reported in the respective column of Table 3, augmented with the interaction term. Likewise, each of the following panels is based on the main regressions, reported in Table 3, augmented by different interaction terms.

The second panel indicates that the relationship between involvement and the transmission of attitudes does not depend on parental education. In three out of four cases, there is no significant interaction effect between involvement and parental education, and for the last case, the transmission of risk attitudes by mothers, we even find that the interaction term is positive. This means that the relation between involvement and similarity in risk attitudes is stronger for lower educated mothers.

While having heterogeneous parents relates to a greater average distance from both parents generally, we do not find a significant interaction effect between the parents' heterogeneity in attitudes and parental involvement on the transmission of the attitudes, as can be seen in the third panel.

In Panel 4 we find weak support for decreasing marginal returns to parental involvement. Concerning the transmission of trust by fathers, we find a significant and positive coefficient for a quadratic term in involvement. However, for the transmission of risk, and for the transmission of trust by mothers, we do not find non-linear effects of involvement. 
Table 4. Heterogeneous Effects of Parental Involvement.

\begin{tabular}{|c|c|c|c|c|}
\hline & \multicolumn{4}{|c|}{ Dependent variables: } \\
\hline & \multicolumn{2}{|c|}{ Risk } & \multicolumn{2}{|c|}{ Trust } \\
\hline & $\begin{array}{c}\text { Mothers } \\
\Delta_{R}^{M C}\end{array}$ & $\begin{array}{c}\text { Fathers } \\
\Delta_{R}^{F C}\end{array}$ & $\begin{array}{c}\text { Mothers } \\
\Delta_{T}^{M C}\end{array}$ & $\begin{array}{c}\text { Fathers } \\
\Delta_{T}^{F C}\end{array}$ \\
\hline Involvement by parent & $\begin{array}{c}-0.095^{* * *} \\
(0.029)\end{array}$ & $\begin{array}{r}-0.057^{*} \\
(0.032)\end{array}$ & $\begin{array}{r}-0.053 \\
(0.034)\end{array}$ & $\begin{array}{c}-0.053 \\
(0.044)\end{array}$ \\
\hline 1 if female & $\begin{array}{l}-0.151^{* * *} \\
(0.034)\end{array}$ & $\begin{array}{r}-0.048 \\
(0.036)\end{array}$ & $\begin{array}{c}0.008 \\
(0.044)\end{array}$ & $\begin{array}{c}0.043 \\
(0.046)\end{array}$ \\
\hline Involvement \# female & $\begin{array}{c}0.048 \\
(0.038) \\
\end{array}$ & $\begin{array}{c}0.048 \\
(0.042) \\
\end{array}$ & $\begin{array}{c}0.016 \\
(0.045) \\
\end{array}$ & $\begin{array}{r}-0.038 \\
(0.059) \\
\end{array}$ \\
\hline Involvement by parent & $\begin{array}{l}-0.066^{* * *} \\
(0.020)\end{array}$ & $\begin{array}{r}-0.034 \\
(0.021)\end{array}$ & $\begin{array}{c}-0.047^{* *} \\
(0.023)\end{array}$ & $\begin{array}{c}-0.076^{* *} \\
(0.030)\end{array}$ \\
\hline Parental education (std) & $\begin{array}{r}-0.028 \\
(0.023)\end{array}$ & $\begin{array}{r}-0.009 \\
(0.024)\end{array}$ & $\begin{array}{c}0.020 \\
(0.029)\end{array}$ & $\begin{array}{c}-0.024 \\
(0.033)\end{array}$ \\
\hline Involvement \# parental education & $\begin{array}{l}0.056^{* * *} \\
(0.019)\end{array}$ & $\begin{array}{r}-0.021 \\
(0.021)\end{array}$ & $\begin{array}{c}-0.020 \\
(0.021)\end{array}$ & $\begin{array}{r}-0.031 \\
(0.029)\end{array}$ \\
\hline Involvement by parent & $\begin{array}{l}-0.060^{* * *} \\
(0.021)\end{array}$ & $\begin{array}{r}-0.027 \\
(0.026)\end{array}$ & $\begin{array}{l}-0.058^{* *} \\
(0.027)\end{array}$ & $\begin{array}{l}-0.090^{* * *} \\
(0.032)\end{array}$ \\
\hline 1 if $\Delta_{\text {Pref }}^{M F}>$ median & $\begin{array}{l}0.418^{* * *} \\
(0.038)\end{array}$ & $\begin{array}{l}0.193^{* * *} \\
(0.039)\end{array}$ & $\begin{array}{l}0.325^{\text {*** }} \\
(0.048)\end{array}$ & $\begin{array}{l}0.489^{* * *} \\
(0.050)\end{array}$ \\
\hline Involvement \# $\Delta_{\text {Pref }}^{M F}>$ median & $\begin{array}{r}-0.010 \\
(0.041)\end{array}$ & $\begin{array}{r}-0.006 \\
(0.044)\end{array}$ & $\begin{array}{c}0.031 \\
(0.048)\end{array}$ & $\begin{array}{c}0.067 \\
(0.061)\end{array}$ \\
\hline Involvement by parent & $\begin{array}{l}-0.063^{* * *} \\
(0.020)\end{array}$ & $\begin{array}{r}-0.031 \\
(0.022)\end{array}$ & $\begin{array}{c}-0.051^{* *} \\
(0.024)\end{array}$ & $\begin{array}{c}-0.070^{* *} \\
(0.029)\end{array}$ \\
\hline Involvement squared & $\begin{array}{c}0.017 \\
(0.013) \\
\end{array}$ & $\begin{array}{c}0.004 \\
(0.017) \\
\end{array}$ & $\begin{array}{c}-0.012 \\
(0.016)\end{array}$ & $\begin{array}{c}0.054^{* *} \\
(0.027) \\
\end{array}$ \\
\hline Involvement by parent & $\begin{array}{l}-0.097^{* * *} \\
(0.033)\end{array}$ & $\begin{array}{l}-0.112^{* * *} \\
(0.030)\end{array}$ & $\begin{array}{c}-0.065^{* *} \\
(0.032)\end{array}$ & $\begin{array}{l}-0.170^{* * *} \\
(0.038)\end{array}$ \\
\hline Involvement \# Pref $^{C}>$ Pref $^{P}$ & $\begin{array}{c}0.041 \\
(0.040)\end{array}$ & $\begin{array}{l}0.159^{* * *} \\
(0.042)\end{array}$ & $\begin{array}{c}0.047 \\
(0.045)\end{array}$ & $\begin{array}{l}0.225^{\text {*** }} \\
(0.057)\end{array}$ \\
\hline
\end{tabular}

Notes: OLS estimates, same controls as in main analysis, but allowing for different slopes in gender, parental education, heterogeneity between parents in attitudes, nonlinearities in parental involvement and direction of the difference in attitudes. All five regressions have the same number of observations as the respective regressions in the main analysis. Robust standard errors in parentheses allow for clustering at the parent level; * significant at $10 \%$; ${ }^{* *}$ significant at $5 \%$; *** significant at $1 \%$.

Panel 5 shows some asymmetric effects with respect to the direction of the difference in attitudes. We add an interaction term with an indicator for the direction of the difference in attitudes and find that for fathers the transmission of attitudes is asymmetric and dependent on the direction of the change in attitudes. For the relation between involvement and the transmission of mothers' attitudes, however, we find no such asymmetries.

\subsubsection{Measurement error}

So far, we have shown that there is a relationship between parental involvement and similarity in attitudes. However, due to measurement error in the proxies, our point estimates might underestimate the true effect. Aside from being rather noisy measures themselves, the proxy variables are all taken from the youth questionnaire, which means that they are measured at one point in time. The measurement error is thus very likely to be correlated across the proxy variables. In this case, the first principal component includes also part of the measurement error, which leads to an attenuation bias in our analysis. We address this problem by constructing an alternative index of parental involvement, which combines the available proxy variables in an efficient way, 
so that the measurement error captured in the resulting index is minimised. The procedure we use has been introduced by Lubotsky and Wittenberg (2006).

To construct this new involvement index, we first regress the difference in attitudes between parents and children on all 13 proxy variables $x_{j}$ and all $K$ control variables $z_{k}$. In particular, for parent-child pair $i$ :

$$
\Delta_{\text {Pref }_{i}}^{P C}=\sum_{j=1}^{13} x_{j i} b_{j}+\sum_{k}^{K} z_{k i} \gamma_{k}+\varepsilon_{i} .
$$

We then use the estimates to construct the involvement index:

$$
I_{i}=-\sum_{j=1}^{13} x_{j i} b_{j}
$$

Finally, we standardise $I$ and obtain our LW parental involvement index. The assumptions made to generate the index are that the proxies and their measurement errors are not correlated with the error term and that all the proxies share an underlying trait. The weights that minimise the attenuation bias are endogenous to the system. The absolute size of the involvement index is therefore not comparable across different samples or estimations with different dependent variables.

Table 5 reports the results of the regressions of the difference between a parent's and a child's attitude (risk and trust) on the level of parental involvement in the upbringing of the child. All the involvement indices used in the four displayed regressions are constructed using the LubotskyWittenberg method. Since the weights that are used to construct the indices are endogenous, the indices are not directly comparable across the specifications. We find point estimates for parental involvement that are larger than the estimates for the PCA involvement index and statistically highly significant in all four scenarios (risk/trust, mother/father). Apart from the change in the point estimates for the involvement index the regression output stays largely similar to the output of our earlier analysis, the correlation coefficients of the control variables stay unchanged, while the total explained variance increases slightly. Given the noisy nature of the proxy variables and the fact that this is only a small selection of possible means of parental involvement the results of this analysis are likely to still underestimate the true effect.

Since all the dependent variables as well as the involvement variables are standardised, the economic significance of our findings is not straightforward. In Table 6 we present our main results in terms of absolute points on the risk and trust scale. For example, a change from the 5th to the 95 th percentile in maternal involvement relates to a decrease in difference in willingness to take risks of 0.620 points on the risk scale that ranges from 0 to 10 . Comparing the size of the effect to the gender difference in willingness to take risks, we see that the effect of a change from the 5 th to the 95 th percentile in maternal involvement exceeds the difference in willingness to take risks between men and women in our sample, which amounts to 0.531 .

\subsection{Parental Involvement and the Formation of Personality Traits}

While it is not always obvious whether a higher degree of risk and trust attitudes is conducive to success, the literature (see, e.g., Almlund et al., 2011, for an overview) indicates that higher levels of certain personality traits, like conscientiousness, internal locus of control and openness, are clearly linked to favourable outcomes. If parents want to mould their children's personality, it is (C) 2021 Royal Economic Society. 
Table 5. LW: The Impact of Parental Involvement on Differences in Risk and Trust.

\begin{tabular}{|c|c|c|c|c|}
\hline & \multicolumn{4}{|c|}{ Dependent variables: } \\
\hline & \multicolumn{2}{|c|}{ Risk } & \multicolumn{2}{|c|}{ Trust } \\
\hline & $\begin{array}{c}\text { Mothers } \\
\Delta_{R}^{M C}\end{array}$ & $\begin{array}{c}\text { Fathers } \\
\Delta_{R}^{F C}\end{array}$ & $\begin{array}{c}\text { Mothers } \\
\Delta_{T}^{M C}\end{array}$ & $\begin{array}{c}\text { Fathers } \\
\Delta_{T}^{F C}\end{array}$ \\
\hline Maternal involvement (LW) & $\begin{array}{c}-0.095^{* * *} \\
(0.017)\end{array}$ & & $\begin{array}{c}-0.063^{* * *} \\
(0.018)\end{array}$ & \\
\hline Paternal involvement (LW) & & $\begin{array}{c}-0.078^{* * *} \\
(0.016)\end{array}$ & & $\begin{array}{c}-0.076^{* * * *} \\
(0.020)\end{array}$ \\
\hline No. of kids in family & $\begin{array}{c}-0.001 \\
(0.016)\end{array}$ & $\begin{array}{c}-0.001 \\
(0.015)\end{array}$ & $\begin{array}{r}-0.029 \\
(0.018)\end{array}$ & $\begin{array}{c}-0.045^{* * *} \\
(0.016)\end{array}$ \\
\hline Age & $\begin{array}{c}0.013 \\
(0.016)\end{array}$ & $\begin{array}{c}0.008 \\
(0.017)\end{array}$ & $\begin{array}{r}-0.007 \\
(0.015)\end{array}$ & $\begin{array}{c}-0.002 \\
(0.016)\end{array}$ \\
\hline 1 if female & $\begin{array}{c}-0.160^{\text {*** }} \\
(0.033)\end{array}$ & $\begin{array}{r}-0.036 \\
(0.034)\end{array}$ & $\begin{array}{c}0.005 \\
(0.046)\end{array}$ & $\begin{array}{c}0.035 \\
(0.044)\end{array}$ \\
\hline Mother years of education & $\begin{array}{c}-0.004 \\
(0.008)\end{array}$ & $\begin{array}{c}0.003 \\
(0.009)\end{array}$ & $\begin{array}{c}0.005 \\
(0.011)\end{array}$ & $\begin{array}{c}0.015 \\
(0.013)\end{array}$ \\
\hline Father years of education & $\begin{array}{c}-0.003 \\
(0.008)\end{array}$ & $\begin{array}{c}-0.003 \\
(0.008)\end{array}$ & $\begin{array}{r}-0.008 \\
(0.010)\end{array}$ & $\begin{array}{r}-0.010 \\
(0.011)\end{array}$ \\
\hline 1 if no migration background & $\begin{array}{c}-0.110^{* *} \\
(0.045)\end{array}$ & $\begin{array}{c}-0.140^{* * *} \\
(0.048)\end{array}$ & $\begin{array}{c}0.060 \\
(0.053)\end{array}$ & $\begin{array}{r}-0.074 \\
(0.056)\end{array}$ \\
\hline $\mathrm{HH}$-income vigintile & $\begin{array}{c}-0.002 \\
(0.004)\end{array}$ & $\begin{array}{c}-0.005 \\
(0.004)\end{array}$ & $\begin{array}{r}-0.004 \\
(0.005)\end{array}$ & $\begin{array}{r}-0.002 \\
(0.005)\end{array}$ \\
\hline Age difference MC & $\begin{array}{r}-0.009^{*} \\
(0.005)\end{array}$ & $\begin{array}{r}-0.000 \\
(0.005)\end{array}$ & $\begin{array}{c}0.000 \\
(0.006)\end{array}$ & $\begin{array}{c}0.004 \\
(0.007)\end{array}$ \\
\hline Age difference FC & $\begin{array}{c}0.007 \\
(0.004)\end{array}$ & $\begin{array}{c}0.005 \\
(0.005)\end{array}$ & $\begin{array}{c}0.007 \\
(0.006)\end{array}$ & $\begin{array}{r}-0.000 \\
(0.006)\end{array}$ \\
\hline 1 if $\Delta_{R}^{M F}>$ median & $\begin{array}{l}0.421^{* * *} \\
(0.038)\end{array}$ & $\begin{array}{l}0.197^{* * * *} \\
(0.038)\end{array}$ & & \\
\hline 1 if $\Delta_{T}^{M F}>$ median & & & $\begin{array}{l}0.323^{* * *} \\
(0.046)\end{array}$ & $\begin{array}{l}0.504^{* * *} \\
(0.047)\end{array}$ \\
\hline Constant & $\begin{array}{r}-0.135 \\
(0.336)\end{array}$ & $\begin{array}{r}-0.126 \\
(0.339)\end{array}$ & $\begin{array}{c}-0.127 \\
(0.336)\end{array}$ & $\begin{array}{c}-0.128 \\
(0.336)\end{array}$ \\
\hline $\begin{array}{l}\text { Observations } \\
R^{2}\end{array}$ & 3,393 & 3,393 & 2,119 & 2,119 \\
\hline$R^{2}$ & 0.069 & 0.029 & 0.034 & 0.072 \\
\hline
\end{tabular}

Notes: The dependent variables are the standardised difference in risk attitudes between mother/father and child in Columns (1)/(2) and in trust attitudes between mothers/father and child in Columns (3)/(4). Risk and trust attitudes are measured in survey questions, explained in Subsection 1.1. The variables of interest, 'Maternal involvement (LW)' and 'Paternal involvement (LW)', are indices, each constructed through the Lubotsky-Wittenberg method (see Subsection 2.1.2) using 13 involvement proxies. The variable ' 1 if $\Delta_{R}^{M F}>$ median' is a binary variable that indicates parents that are heterogeneous in their risk attitudes, and ' 1 if $\Delta_{R}^{M F}>$ median' analogously for trust. In addition to the listed variables we also control for the year of the attitudes elicitation. Clustered standard errors; * significant at $10 \%$; ${ }^{* *}$ significant at $5 \% ;{ }^{* * *}$ significant at $1 \%$.

plausible to assume that they would like to equip their children with a personality that contributes to life success. As a result, they will instill higher levels of favourable traits in their children rather than simply transmitting their own traits.

We therefore extend our analysis, investigating whether parental involvement is associated with higher levels of internal locus of control and advantageous Big Five personality traits. In particular, we regress the level of a child's personality trait on parental involvement and control variables. Alongside these results we provide estimates for the relationship between involvement and similarity in parents' and their child's personality. ${ }^{17}$

17 While the transmission of own preferences and traits is aligned with models of cultural transmission, e.g., in Bisin and Verdier, (2001), investment in affecting the absolute level of the child's preference or personality is more in accordance with the model of Doepke and Zilibotti (2017). 
Table 6. Impact of an Increase in Involvement on the Difference in Attitude.

\begin{tabular}{|c|c|c|c|c|}
\hline \multicolumn{5}{|l|}{ Risk: Mother-Child $\left(\Delta_{R}^{M C}\right)$} \\
\hline \multirow[b]{2}{*}{ A change from the } & \multicolumn{2}{|c|}{ PCA involvement index } & \multicolumn{2}{|c|}{ LW involvement index } \\
\hline & \multicolumn{2}{|c|}{ std $\quad a b s$} & std & abs \\
\hline 25th-75th percentile in involvement & -0.079 & -0.155 & -0.129 & -0.253 \\
\hline 5th-95th percentile in involvement & -0.199 & -0.392 & -0.315 & -0.620 \\
\hline \multicolumn{5}{|l|}{ Trust: Mother-Child $\left(\Delta_{T}^{M C}\right)$} \\
\hline & \multicolumn{2}{|c|}{ PCA involvement index } & \multicolumn{2}{|c|}{ LW involvement index } \\
\hline A change from the & std & abs & std & abs \\
\hline 25 th-75th percentile in involvement & -0.058 & -0.024 & -0.083 & -0.034 \\
\hline 5th-95th percentile in involvement & -0.146 & -0.060 & -0.207 & -0.085 \\
\hline \multicolumn{5}{|l|}{ Risk: Father-Child $\left(\Delta_{R}^{F C}\right)$} \\
\hline & \multicolumn{2}{|c|}{ PCA involvement index } & \multicolumn{2}{|c|}{ LW involvement index } \\
\hline A change from the & std & abs & std & abs \\
\hline 25 th -75 th percentile in involvement & -0.031 & -0.058 & -0.104 & -0.193 \\
\hline 5th-95th percentile in involvement & -0.078 & -0.145 & -0.257 & -0.478 \\
\hline \multicolumn{5}{|l|}{ Trust: Father-Child $\left(\Delta_{T}^{F C}\right)$} \\
\hline & \multicolumn{2}{|c|}{ PCA involvement index } & \multicolumn{2}{|c|}{ LW involvement index } \\
\hline A change from the & std & abs & std & abs \\
\hline 25th-75th percentile in involvement & -0.064 & -0.027 & -0.099 & -0.042 \\
\hline 5th-95th percentile in involvement & -0.163 & -0.069 & -0.259 & -0.109 \\
\hline
\end{tabular}

Notes: We report the change in difference in attitude between parent and child, resulting from an increase in parental involvement from the 25 th to the 75 th percentile (and 5 th to 95 th percentile respectively). For each of the four specifications (attitude and parent combination) we report standardised and attitude-point effects based on the results of the estimation with both involvement indices.

Table 7 provides the results of both types of regressions. Each row presents the coefficients of the respective parent's involvement variable from regressions of a particular personality trait or attitude of the child, both in levels in terms of the distance to the respective trait or attitude of the parent. ${ }^{18}$ Since the attitudes and personality traits are gathered from different waves of the SOEP, the samples do not coincide between the different attitudes and traits. The sample size is, however, the same for both parents and across the specification in levels and in differences for a given trait.

The same control variables as in our main analysis are included in every regression. For each attitude and parent we highlight the coefficients (on similarity or level of attitude) that are statistically significant at the 5\% level. As can be inferred from Table 8, parent's involvement has a positive impact on the level of locus of control, which means that children of more involved parents feel that they have more control over their own lives. Likewise, for most personality traits involvement is related more strongly to the level than to the distance to a parent. In fact, higher parental involvement is associated with higher levels of openness to experience, conscientiousness, extraversion and agreeableness. Involvement in the upbringing of children is related to a more favourable personality of children. Note that we also find that more involved mothers (fathers) have children that are more similar to them in terms of openness to experience (conscientiousness), but the effects are weaker than the estimated effects on levels.

\footnotetext{
18 We provide the complete regression output for all specifications, and the results of the same regressions without control variables in the supplementary material.
} 
Table 7. Level and Distance in Attitudes on Parental Involvement.

\begin{tabular}{|c|c|c|c|c|c|}
\hline & \multicolumn{4}{|c|}{ Dependent variables: } & \multirow[b]{3}{*}{$\mathrm{N}$} \\
\hline & \multicolumn{2}{|c|}{ Mother } & \multicolumn{2}{|c|}{ Father } & \\
\hline & Level & Distance & Level & Distance & \\
\hline Locus of control & $\begin{array}{c}0.053 \\
(0.035)\end{array}$ & $\begin{array}{c}-0.004 \\
(0.880)\end{array}$ & $\begin{array}{c}0.076 \\
(0.007)\end{array}$ & $\begin{array}{c}-0.055 \\
(0.057)\end{array}$ & 2,274 \\
\hline Big Five: openness & $\begin{array}{c}0.090 \\
(0.001)\end{array}$ & $\begin{array}{r}-0.079 \\
(\mathbf{0 . 0 0 2})\end{array}$ & $\begin{array}{c}0.112 \\
(0.000)\end{array}$ & $\begin{array}{r}-0.010 \\
(0.744)\end{array}$ & 1,919 \\
\hline Big Five: conscientiousness & $\begin{array}{c}0.076 \\
(0.002)\end{array}$ & $\begin{array}{r}-0.044 \\
(0.088)\end{array}$ & $\begin{array}{c}0.090 \\
(0.002)\end{array}$ & $\begin{array}{r}-0.075 \\
(0.012)\end{array}$ & 1,915 \\
\hline Big Five: extraversion & $\begin{array}{c}0.098 \\
(0.000)\end{array}$ & $\begin{array}{c}-0.023 \\
(0.348)\end{array}$ & $\begin{array}{c}0.120 \\
(0.000)\end{array}$ & $\begin{array}{c}0.016 \\
(0.588)\end{array}$ & 1,918 \\
\hline Big Five: agreeableness & $\begin{array}{c}0.104 \\
(0.000)\end{array}$ & $\begin{array}{c}-0.031 \\
(0.224)\end{array}$ & $\begin{array}{c}0.096 \\
(0.001)\end{array}$ & $\begin{array}{r}-0.010 \\
(0.734)\end{array}$ & 1,926 \\
\hline Big Five: neuroticism & $\begin{array}{c}0.007 \\
(0.777)\end{array}$ & $\begin{array}{r}-0.065 \\
(0.007)\end{array}$ & $\begin{array}{c}0.013 \\
(0.668)\end{array}$ & $\begin{array}{c}-0.021 \\
(0.495)\end{array}$ & 1,924 \\
\hline Risk & $\begin{array}{c}-0.011 \\
(0.594)\end{array}$ & $\begin{array}{c}-0.064 \\
(0.001)\end{array}$ & $\begin{array}{r}-0.018 \\
(0.417)\end{array}$ & $\begin{array}{r}-0.029 \\
(0.180)\end{array}$ & 3,393 \\
\hline Trust & $\begin{array}{c}0.029 \\
(0.233)\end{array}$ & $\begin{array}{c}-0.047 \\
(0.041)\end{array}$ & $\begin{array}{c}0.074 \\
(0.010)\end{array}$ & $\begin{array}{r}-0.062 \\
(0.031)\end{array}$ & 2,119 \\
\hline
\end{tabular}

Notes: This table lists the OLS coefficients of the PCA involvement variables for mothers and fathers in regressions on different preference and attitude and personality measures. The control variables are the same as in the main specification, see Table 3. In Columns (1) and (3) the dependent variable is the child's level of the respective attitude. In Columns (2) and (4) the dependent is the distance in the attitude between the respective parent and the child. $p$-values in brackets.

Table 8. Changes in Risk Attitudes on Changes of Family Members' Attitudes.

\begin{tabular}{lccc}
\hline \hline & \multicolumn{3}{c}{ Dependent variables: } \\
\cline { 2 - 4 } & $\Delta_{t}$ Risk child & $\Delta_{t}$ Risk mother & $\Delta_{t}$ Risk father \\
\hline$\Delta_{t-1}$ Risk child & $-0.445^{* * *}$ & -0.015 & $0.021^{*}$ \\
& $(0.011)$ & $(0.011)$ & $(0.012)$ \\
$\Delta_{t-1}$ Risk mother & $0.037^{* * *}$ & $-0.462^{* * *}$ & 0.011 \\
& $(0.012)$ & $(0.010)$ & $(0.013)$ \\
$\Delta_{t-1}$ Risk father & $-0.032^{* * *}$ & -0.006 & $(0.011)$ \\
Constant & $(0.011)$ & $-0.240^{* * *}$ & $(0.011)$ \\
& $-0.450^{* * *}$ & $(0.081)$ & $\left(0.182^{* *}\right.$ \\
Observations & $(0.086)$ & 6,791 & 6,791 \\
$R^{2}$ & 6,791 & 0.262 & 0.274 \\
\hline \hline
\end{tabular}

Notes: OLS estimates, robust standard errors in parentheses; ${ }^{*}$ significant at $10 \% ;{ }^{* *}$ significant at $5 \% ;{ }^{* * *}$ significant at $1 \%$.

For neuroticism we find a significant correlation between mother's involvement and similarity, but do not observe this for fathers.

Importantly, we find for risk and trust attitudes that the level effects are indeed insignificant. ${ }^{19}$ In sum, these results strongly support the hypothesis that parental involvement is related to the formation of the children's preferences. It is unlikely that the correlation between parental involvement and similarity in preferences of parents and their children comes about because parents want to be more involved with children who are similar to them in the first place. If it is similarity that causes involvement, it is hard to explain the result, that involvement is associated

19 In the Appendix we also provide the results of the two types of regressions for the domain specific risks (Table A5). In case of the domain specific risk attitudes it is more difficult to predict whether the level or the transmission effect should be stronger. In the domains health and driving a level effect seems more likely, which coincides with our results. 
with higher levels of favourable traits in children. Yet, a causal effect of parental involvement on the formation of preferences and personality is consistent with the whole set of findings. To gain a better understanding of these two dimensions of the outcome variable, we investigate in the next section how parental involvement and parental traits interact in the formation of personality.

Concluding this section, if we apply the Lubotsky-Wittenberg method, reducing measurement error, we find stronger effects for both levels and distance, and the coefficients on the similarity become statistically significant.

\subsection{Heterogeneous Treatment Effects}

We conjecture that benevolent parents, in the best interest of their children, try to mould their children's characters in order to increase their chances for success in life. Although we expect that all parents want to inculcate higher levels of favourable traits in their children, parents who have high levels of these traits themselves might be more efficient in instilling them in their children. Being a role model, for example, could intensify the effect of involvement.

We therefore study the heterogeneous effects of involvement at different levels of parent's own trait. To do so, we estimate a similar model to the one on levels, but now also include the parent's own trait and an interaction term between the parent's trait and involvement. ${ }^{20}$

Figures 4 and 5 show the conditional marginal effects of parental involvement on children's attitudes and traits. Specifically, in Figure 4 each graph plots the marginal effects of involvement on a particular attitude or personality trait of a child for given level of the same maternal attitude or trait. A positive slope indicates that the marginal effect of involvement increases in the level of the mother's attitude or trait. The vertical location of the line indicates whether the marginal effect is positive or negative, i.e., if the line crosses the $\mathrm{x}$-axis, the marginal effect changes sign. As a result, the slope and location of the conditional marginal effect function reveals whether parental involvement interacts with parental attitudes/traits to boost similarity of parents' and children's traits and attitudes or to exacerbate or mute the impact on the level of children's attitudes/traits.

The first panel of Figure 4 on risk attitudes shows that the slope of the conditional marginal effect function is increasing and crosses the $\mathrm{x}$-axis at the midpoint of the scale. The fact that the conditional marginal effect of the interaction between involvement and mother's attitudes crosses the $\mathrm{x}$-axis at the midpoint of the scale indicates that risk attitudes and involvement interact to boost similarity. Involvement reduces children's willingness to take risks for mothers with a willingness to take risks smaller than a value of 5 on the risk scale and increases it for mothers with a value that exceeds 5. Importantly, these marginal effects become stronger (reflected by the positive slope of the conditional marginal effect function) if we move towards the tails of the distribution of mother's risk attitudes. This means that additional involvement of mothers with high willingness to take risks is associated with an even stronger increase of their children's willingness than the same incremental increase of involvement of mothers with (slightly) lower willingness to take risks. For mothers with low willingness to take risks, involvement reduces

20 We now estimate for each attitude or trait $(A T)$

$$
A T^{C}=\alpha+\beta_{1} \operatorname{Inv} v^{P}+\beta_{2} A T^{P}+\beta_{3}\left(\operatorname{Inv} v^{P} \times A T^{P}\right)+\gamma \mathbf{Z}+\varepsilon_{i},
$$

and report the marginal effect of the parent's involvement $\left(\operatorname{Inv}{ }^{P}\right)$

$$
\frac{d\left(A T^{C}\right)}{d\left(\operatorname{Inv} v^{P}\right)}=\beta_{1}+\beta_{3} A T^{P} .
$$



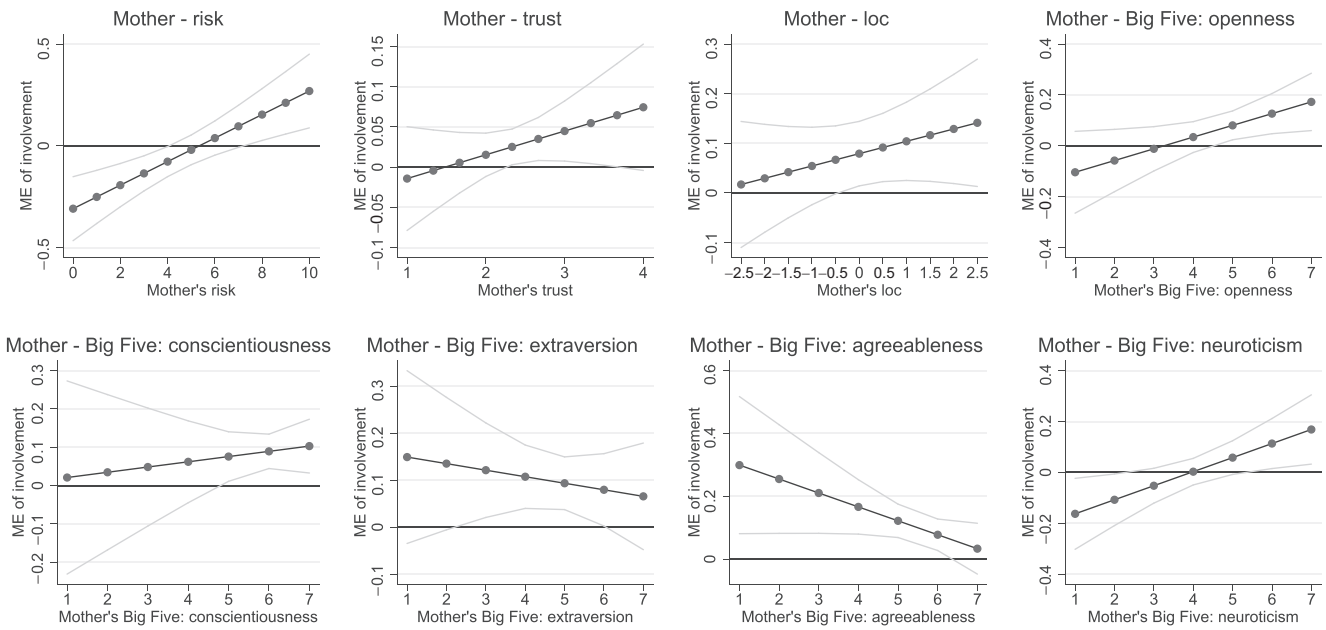

Fig. 4. Marginal Effect of Mother's Involvement on the Child's Preferences and Personality, Conditional on the Mother's Own Traits.

Notes: Each graph shows the effect of a one standard deviation increase of mothers' involvement on the child outcome, for a given level of the preference or personality of the mother.

Data source: SOEP, v32.
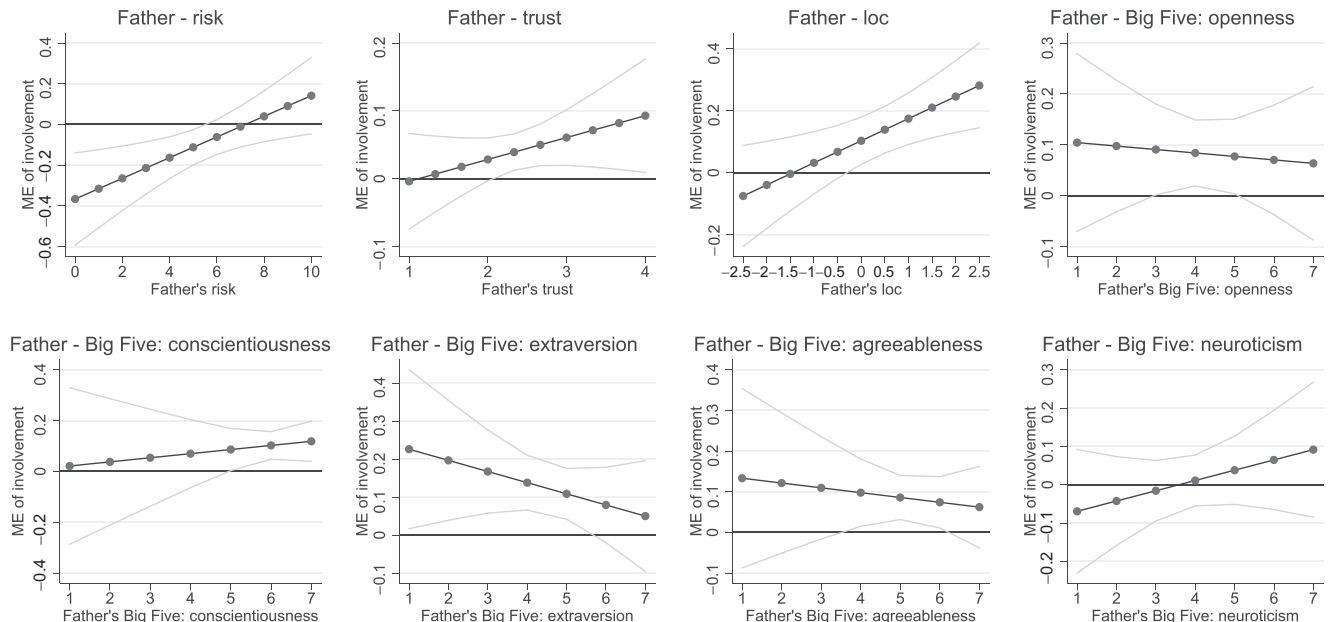

Fig. 5. Marginal Effect of Father's Involvement on the Child's Preferences and Personality, Conditional on the Father's Own Traits.

Notes: Each graph shows the effect of a one standard deviation increase of fathers' involvement on the child outcome, for a given level of the preference or personality of the father.

Data source: SOEP, v32.

their children's willingness to take risk. This effect is stronger the less willing mothers are to take risks.

A different pattern is observed for locus of control. Although the size of the marginal effect of involvement increases with mothers' internal locus, involvement is never associated with 
decrease in children's locus of control. In other words, involvement always tends to increase children's locus of control, but the effect of involvement is stronger the higher the internal locus of control of the mother is. We find a similar pattern for conscientiousness. For extraversion and agreeableness, involvement always has a positive impact on the level, but this effect is dampened for higher maternal levels of the respective trait. Figure 5 shows similar patterns for father's involvement.

\subsection{Causal Nature of the Relationship between Parental Involvement and the Transmission of Personality and Preferences}

In this subsection we address the causal nature of the relationship between parental involvement and the transmission of personality and preferences. The identification of a causal effect of parental involvement on this transmission is challenging as two requirements have to be met. First, we would need to be able to exogenously alter parental involvement (i.e., ideally randomly assign the intensity of parental involvement to children), and at the same time we would need to ascertain that the intervention that changes parental involvement does not directly affect children's preferences (Heckman, 2005). ${ }^{21}$ A second challenge, which applies particularly when the effect of the treatment is heterogeneous, is that the counterfactual is not readily observed (i.e., we cannot observe the same child growing up with different levels of parental involvement at the same time). Therefore, we would have to find a suitable comparison group. An additional complication for the measurement of effect sizes arises when the impact of parental involvement evolves over time.

Despite these challenges, there are some avenues that we can pursue to at least address some of the most pressing concerns that could refute a causal effect of parental involvement on the transmission of preferences and personality, namely the concern of a spurious correlation and the concern of reverse causality. ${ }^{22}$

\subsubsection{Is the relationship driven by omitted variables?}

To avoid our results arising from a spurious correlation, i.e., that omitted variables drive our results, we already used control for factors that, according to the literature, are related to children's preferences and likely correlate with the parents' involvement, such as the parents' education, income or migration status, as well as the child's gender (Alesina and La Ferrara, 2002; Dohmen et al., 2011). However, there could be other unobservable factors that affect both children's personality and preferences and parents' involvement. In order to gauge the impact of such unobserved, and hence omitted, variables on the estimated relationship between parental involvement and similarity in risk and trust attitudes of parents and their children, we follow the method suggested by Oster (2019). To this end, we estimate the share of unobserved confounders in $R^{2}$ relative to that of observable variables, that would be necessary to overturn our results on parental involvement. For the similarity in trust between mother and child we find that 'adding unobservables' similar to the observable confounders would strengthen the coefficient on mothers involvement, while for fathers the coefficient would cross zero if we would add factors that explain a fraction of at least 0.48 of that explained by the regressors that are already included in

\footnotetext{
${ }^{21}$ Random assignments of parental involvement is not feasible due to legal and ethical constraints.

22 Note that simultaneity, i.e., a two-way causal relationship, which would arise, for example if parental involvement affects children's preferences and children's preferences then trigger parental involvement, does not rule out a causal impact of parental involvement on the transmission of personality and preferences.
} 
our main model. Since we already control for factors in our main analysis that have been argued to be key determinants of transmission of trust in the literature, it is unlikely that there is a set of unobservable factors that are sufficiently important to overturn our results. For risk attitudes, the critical fractions of explanatory power of unobservable factors relative to that of included regressors are, however, smaller. They amount to 0.15 and 0.06 for mothers and fathers, respectively. While these results suggests that, in our sample, it is harder to reject the possibility that unobserved factors drive the observed relationship between parental involvement and similarity on risk attitudes of parents and their children, it should be noted that the relationship between fathers' involvement and similarity in risk attitudes is also weakest in our main specification in Table 3.

\subsubsection{Can reverse causality drive our findings?}

Reverse causality can arise for three reasons: $(i)$ it could be conjectured that parents' attitudes are changed by children and that the child's influence is stronger the more the parent is involved, (ii) the observed correlation might be caused by biased responses. In particular, it might be conjectured that children who are more similar to their parents systematically state retrospectively that their parents were more involved, (iii) it might be the case that parents are more involved with children who are more similar to them, for example because they enjoy interaction with more similar kids. In order to address these three issues, we conduct additional analyses, using additional data. We focus on the transmission of risk attitudes since the information on the willingness to take risks satisfies the requirements needed for these additional analyses. Firstly, risk attitudes are measured frequently enough to allow longitudinal analyses. Secondly, an additional data set on younger children, the pupils survey, also contains the risk question.

\section{Is there an impact of children's attitudes on parents' attitudes?}

A causal interpretation of our results relies on the assumption, that parents' attitudes are well established and not dependent on their children's attitudes. While there is a growing body of evidence that suggests that risk attitudes are fairly stable in adults, there might still be the possibility that children can shape parents' preferences. ${ }^{23}$ Even though the literature suggests that preferences and personality traits become much less malleable after adolescence, it cannot be fully excluded a priori that parents' preferences become more similar to those of their children if they are more involved with the children. To test this hypothesis, we investigate the impact of changes in parents' stated risk attitudes on changes their children's stated risk attitudes and vice versa. For this additional test we construct a panel of young adults (19-32) and their parents with repeated risk attitude measures. The results in Table 8 show a significant effect of lagged changes in attitudes of parents on the children's attitudes, but little to no effects in the opposite direction. Parents' attitudes appear to be independent of their children's past developments in attitudes and changes in their partners' attitudes. The risk attitudes of young adults, however, still partially depend on their parents' risk attitudes.

\section{Are retrospective parental involvement measures endogenous?}

The optimal timing and way to elicit parental involvement is not straightforward. It might be beneficial to measure the timing and intensity of parental involvement, particularly if the effect of parental involvement on the formation of preferences and attitudes varies over time. However, if parental involvement is stable over time-or at least rank-order stable-measuring parental involvement only once is less of a concern. The second issue is how the information on parenting

\footnotetext{
${ }^{23}$ See Josef et al. (2016) for a discussion of the stability of risk preferences.
} 
is gathered. Since quality and quantity of parenting efforts are not directly observable, we mostly have to rely on self-reports from either the parents or the children. There is some evidence that the reports by young adults about their own upbringing are a better measure to predict achievement than reports about parenting by their parents (Aunola et al., 2000). This evidence supports our use of retrospective questions to the children to elicit parental involvement.

However, using children's self-reports to investigate the transmission of attitudes could potentially invite reversed causality issues. A suggested path is that children who are more similar to their parents remember the interaction with their parents more positively and answer the questions on parental involvement more favourably.

We address this problem by making use of a small sub-sample of the SOEP that provides parenting measures that are based on parents' answers. Starting with the cohort of children born to SOEP households in 2002 and 2003 the SOEP survey asks parents a battery of questions about their young children. Parents answer questions regarding the behaviour of their child and about their own role and expectations in the upbringing of the child at different stages of the childhood. The survey is administered to both parents when their child is seven- or eight-years-old and it includes several measures of parenting style (see Richter et al., 2013, for information on the parenting style indices). These children were then interviewed personally for the first time in the pupil survey at the age of 11 or 12 . The first cohort of children completed this survey in 2014. The interviewed children are 11- to 12-years-old. In this survey the children answer the general risk question. ${ }^{24}$ We use this information of children's self-reported risk attitudes of all children for whom we know the parenting style their parents reported four years earlier, i.e., when the children were aged seven or eight, in order to assess the relation of parental efforts on the transmission of attitudes. We focus on the parenting style scale for emotional warmth, since the items to this scale are closest to our parental involvement measure. ${ }^{25} \mathrm{We}$ find a negative relation between the mother's reported emotional warmth and distance between mother and child in risk attitudes. However, due to a small sample size and large standard errors the results are not statistically significant. Controlling for the child's gender and the parents' years of education we find that an increase of one point on the emotional warmth scale (1-5) relates to -0.25 standard deviations in distance in risk attitudes between mothers and child. ${ }^{26}$ The relation between fathers emotional warmth and distance in risk attitudes is also negative, but closer to zero in this sample. These results indicate that more parental involvement is associated with a higher degree of similarity between parents' and children's preferences later in their children's life, casting doubt on the explanation that the observed correlation between parental involvement and similarity in preference is driven by biased retrospective reporting of parental involvement.

Ideally, we would like to present additional direct evidence that shows that our retrospective measure of parental involvement is not biased. This is, however, not possible as we do not have an objective benchmark. Hence, we provide more indirect evidence on quality of the retrospective measure. For this, we focus on the correlation of answers of siblings about their parents' involvement. Of course, this could differ by sibling and circumstances, although this is not clear a priori. In order to limit this possibility we focus on twins, who arguably are affected by the same parental behaviour at the same time during their life. We use the correlation of answers

\footnotetext{
24 The question is asked in exactly the same way as in the adult questionnaire.

25 The emotional warmth index is based on the following three questions: (i) I show my child with words and gestures that I care about him/her, (ii) I console child when he/she is sad, (iii) I praise my child.

26 The full regression outputs for the analysis with parents contemporary and average risk preferences are reported in the supplementary material.
} 

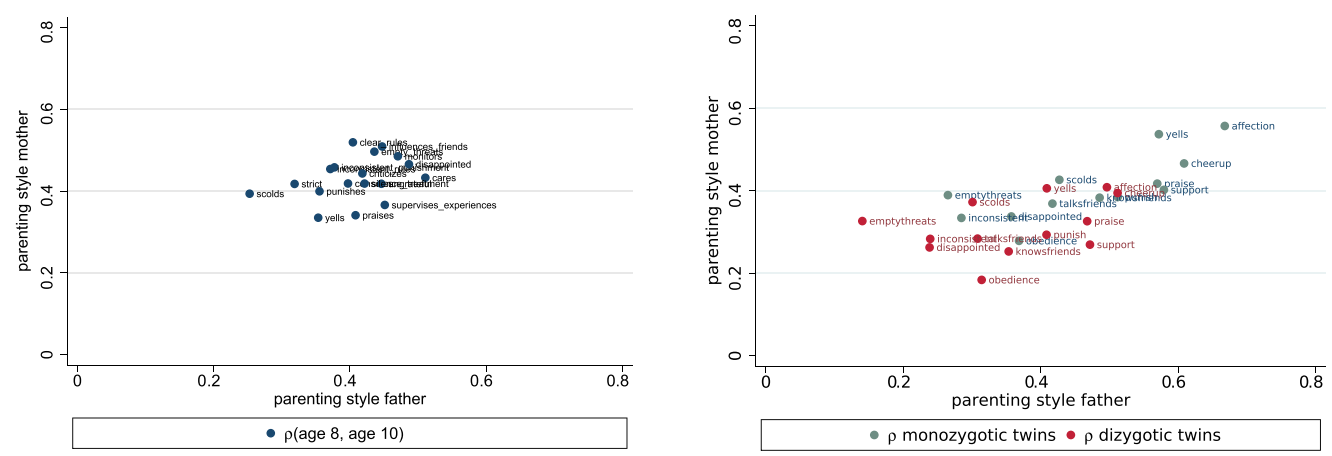

Fig. 6. Correlations in Reported Parenting Style.

Notes: Left panel: test-retest correlations on parents answers to parenting style items, at the child's age eight and ten. Own calibration; data source: SOEP, v32. Right panel: correlation in answers to parenting style questions between twins. Own calibration; data source: TwinLife.

of the two twins in order to gauge the degree of measurement error. We then compare the extent of potential measurement error in children's answers to the test-retest correlation of parent's answers to the parenting style questions that were collected when the children were eight and ten years of age.

Since the children cohort is still too young to have been part of the youth survey, we can not directly compare the parents' answers to the children's answers. We can however compare the quality of answers by parents to the quality of answers of siblings. The parents of the children cohort have answered the same parenting style questions twice, at age eight and ten of the child. In Figure 6 we compare the correlations between two answering waves of parents' answers to the correlation in answers to parenting style questions by twins. We use the TwinLife study for that purpose to get a sufficiently large amount of data points. The test-retest correlations of the parents' answers are between 0.4 and 0.6 for all items, as the graph on the right hand side illustrates. The correlation of answers by twins are primarily between 0.2 and 0.7 , with stronger correlations between monozygotic twins than between dizygotic twins. The similar range of correlations between siblings and between answers of a parent at different points in time suggests that our retrospective measure of parental involvement is not biased.

\section{Does similarity lead to more involvement?}

We have suggested that higher parental involvement leads to stronger similarity in risk and trust attitudes of parents and their children. One could, however, challenge such an interpretation of the observed correlation based on the argument that similarity between parents and children leads to higher involvement. Such an alternative explanation would entail, however, that similarity among other dimensions of personality, as measured for example by the Big Five personality traits, would also be associated with higher levels of parental involvement. As we show in Subsection 2.2, this is not the case. Finding that for personality traits the levels matter more mitigates the concern of endogenous parental involvement, since the benefits of increased interaction with a more similar child are no longer an issue.

We provide additional evidence that questions the conjecture that similarity drives parental involvement by investigating birth-order effects and differences between siblings. 
Firstly, we observe that the first child is on average more similar to the parent in risk attitudes (the difference in similarity to the mother is 0.23 , and 0.15 to the father, though only the difference for mothers is significant at the $5 \%$ level). If we assume that the attitudes dispositions are randomly distributed among children with the same parents, parents should be most involved with the most similar child. Thus there should be no birth order effect in the similarity to the parents. Instead we observe that the parents who have more than one child are on average more involved in the first child's upbringing ( 0.1 standard deviations difference between the first and the later child in parental involvement from mothers and fathers, both differences are statistically significant at the $5 \%$ level).

A different approach would be to investigate occurrences where the first child happens to be very similar in attitudes and traits to the parent. If parents are more involved with children that are similar to them, and if there are no birth-order effects in the occurrence of attitudes, we should expect parents with a very similar first child to be less involved with the upbringing of the second child. Using the cases of siblings in our sample, we estimate the probability that the parents are more involved with the first child, based on the distance in risk attitudes between the parent and the child. We do not find support for any relation between the match in attitudes of the first child and the parent and the distribution of parental efforts between the children. The marginal effects of the similarity in risk attitudes between the mother and the first child on the probability that the mother is more involved with the first child than with the later child is small and statistically not different from zero, independent on whether we consider only same-sex siblings, ${ }^{27}$ or any constellation of siblings. For fathers the marginal effects are also statistically insignificant, while the sign is even inverted for same sex siblings.

\section{Conclusion}

Our analysis reveals that parents can affect their children's preferences, attitudes and personality. Parents who are more involved in the lives of their children have children who are more similar to them in dimensions of personality for which the optimal level depends on conditions of the environment, as is the case for risk and trust attitudes. At the same time, parental involvement is associated with higher levels of traits in dimensions in which a higher level is conducive to success in life, e.g., conscientiousness. The effects of involvement are similar for mothers and fathers. Our results indicate that parents are equipped with a technology that enables them to shape the preferences of their children.

While our data do not allow us to directly ascertain that parental involvement causally affects preferences, we provide ample evidence that preempt the most obvious reservations against a causal interpretation. First, there is no evidence of reversed causality. Statistical tests indicate that parental preferences and attitudes do not respond to children's attitudes over time. Second, we show that the involvement decision is not determined by similarities of parents and children. When it comes to personality traits, for example, parental involvement is not associated with similarity in personality of parents and their children, but is rather related to the level of the child's traits. Moreover, we do not find evidence that parental involvement differs across same-sex siblings, even though parent-child similarity might differ between siblings. Third, the relationship between parental involvement and similarity in preferences is not a consequence of a specific answering

\footnotetext{
27 We exclude mixed sibling couples because there could be differences in levels of involvement by gender of the child (see, e.g., Baker and Milligan, 2016).
}

(C) 2021 Royal Economic Society. 
behaviour, where children who are more similar to their parents answer the questions on parental involvement more favourably.

Our results have important implications. Evidence that a mechanism exists that enables parents to affect the transmission of preferences by investments, such as parental involvement, not only supports the view that preferences are malleable during childhood, but also that preferences can purposefully be shaped by parenting (Doepke and Zilibotti, 2017). Our findings thereby lend additional support to a central assumption of prominent theoretical models of cultural transmission, namely that parents can affect the intergenerational transmission of preferences and attitudes through nurture (Bisin and Verdier, 2001). As it is very likely that other investment opportunities, beyond the ones documented in this article (e.g., the choice of neighbourhood in which the child grows up), exist that allow parents to directly or indirectly mould their children's attitudes, beliefs, and preferences, we interpret our findings as a lower bound for the effect of parental investments on the intergenerational transmission of preferences and attitudes.

This result is of great consequence for our understanding of intergenerational mobility and for the design and appraisal of policies that affect social mobility. While the malleability of preferences suggests scope for policy intervention during childhood, we deliberately have not indicated that policymakers should aim at influencing the formation of preferences. Too little is known about whether such changes are desirable. For example, it is not obvious what bundles of preferences are superior in different conditions, and we want to caution policymakers about jumping to conclusions too quickly.

\section{Appendix A}

Table A1. Factor-Loadings for PCA Parental Involvement Measures.

\begin{tabular}{lcc}
\hline \hline & $\begin{array}{c}\text { Involvement } \\
\text { mother }\end{array}$ & $\begin{array}{c}\text { Involvement } \\
\text { father }\end{array}$ \\
\hline Parents show interest in performance & 0.227 & 0.132 \\
Parents take part in parents-evening & 0.156 & 0.103 \\
Parents come to teacher office hours & 0.121 & 0.055 \\
Parents visit teacher outside office hours & 0.088 & 0.026 \\
Parents involved in at least one school activity & 0.174 \\
Mother helps with studying & 0.203 \\
Mother talks about things you do & 0.328 & 0.107 \\
Mother talks about things that worry you & 0.158 & 0.356 \\
Mother asks you prior to making decision & 0.384 & 0.363 \\
Mother expresses opinion on something you do & 0.381 & 0.228 \\
Mother is able to solve problems with you & 0.383 & 0.364 \\
Mother asks your opinion on family matters & & 0.240 \\
Mother gives reason for making decision & & 0.368 \\
Father helps with studying & & 0.388 \\
Father talks about things you do & & 0.374 \\
Father talks about things that worry you & & 0.376 \\
Father asks you prior to making decisions & & 0.385 \\
Father expresses opinion on something you do & & \\
Father is able to solve problems with you & & \\
Father asks your opinion on family matter & & \\
Father gives reason for making decision & & \\
\hline \hline
\end{tabular}


Table A2. PCA: The Impact of Parental Involvement on Differences in Risk and Trust.

\begin{tabular}{|c|c|c|c|c|}
\hline & \multicolumn{4}{|c|}{ Dependent variables: } \\
\hline & \multicolumn{2}{|c|}{ Risk } & \multicolumn{2}{|c|}{ Trust } \\
\hline & $\begin{array}{c}\text { Mothers } \\
\Delta_{R}^{M C}\end{array}$ & $\begin{array}{c}\text { Fathers } \\
\Delta_{R}^{F C}\end{array}$ & $\begin{array}{c}\text { Mothers } \\
\Delta_{T}^{M C}\end{array}$ & $\begin{array}{c}\text { Fathers } \\
\Delta_{T}^{F C}\end{array}$ \\
\hline Maternal involvement (PCA) & $\begin{array}{c}-0.086^{* * *} \\
(0.020)\end{array}$ & & $\begin{array}{r}-0.038^{*} \\
(0.022)\end{array}$ & \\
\hline Paternal involvement (PCA) & & $\begin{array}{r}-0.037^{*} \\
(0.021)\end{array}$ & & $\begin{array}{c}-0.068^{* *} \\
(0.029)\end{array}$ \\
\hline Constant & $\begin{array}{r}-0.007 \\
(0.018)\end{array}$ & $\begin{array}{c}-0.007 \\
(0.018)\end{array}$ & $\begin{array}{c}-0.013 \\
(0.022)\end{array}$ & $\begin{array}{c}0.003 \\
(0.023)\end{array}$ \\
\hline Observations & 3,393 & 3,393 & 2,119 & 2,119 \\
\hline$R^{2}$ & 0.007 & 0.001 & 0.001 & 0.003 \\
\hline
\end{tabular}

Notes: OLS estimations, same specifications as in Table 3, but without any control variables. Robust standard errors in parentheses allow for clustering at the parent level; * significant at 10\%; ** significant at 5\%; *** significant at $1 \%$.

Table A3. Parental Involvement on Age Adjusted Differences in Risk and Trust Attitudes.

\begin{tabular}{|c|c|c|c|c|}
\hline & \multicolumn{4}{|c|}{ Dependent variables: } \\
\hline & \multicolumn{2}{|c|}{ Risk } & \multicolumn{2}{|c|}{ Trust } \\
\hline & $\begin{array}{l}\text { Mothers } \\
\text { adj. } \Delta_{R}^{M C}\end{array}$ & $\begin{array}{c}\text { Fathers } \\
\text { adj. } \Delta_{R}^{F C}\end{array}$ & $\begin{array}{l}\text { Mothers } \\
\text { adj. } \Delta_{T}^{M C}\end{array}$ & $\begin{array}{l}\text { Fathers } \\
\text { adj. } \Delta_{T}^{F C}\end{array}$ \\
\hline Maternal involvement (PCA) & $\begin{array}{c}-0.038^{* *} \\
(0.019)\end{array}$ & & $\begin{array}{c}-0.049^{* *} \\
(0.023)\end{array}$ & \\
\hline Paternal involvement (PCA) & & $\begin{array}{r}-0.025 \\
(0.021)\end{array}$ & & $\begin{array}{r}-0.052^{*} \\
(0.029)\end{array}$ \\
\hline Constant & $\begin{array}{c}0.118 \\
(0.358)\end{array}$ & $\begin{array}{r}-0.287 \\
(0.356)\end{array}$ & $\begin{array}{r}-0.049 \\
(0.321)\end{array}$ & $\begin{array}{r}-0.170 \\
(0.339)\end{array}$ \\
\hline Observations & 3,393 & 3,393 & 2,119 & 2,119 \\
\hline$R^{2}$ & 0.031 & 0.035 & 0.031 & 0.068 \\
\hline
\end{tabular}

Notes: OLS estimates, all control variables from the main models are included. Robust standard errors in parentheses allow for clustering at the parent level; * ${ }^{*}$ significant at $10 \% ;{ }^{* *}$ significant at $5 \%$; ${ }^{* * *}$ significant at $1 \%$. 
Table A4. Level and Distance in Attitudes on Parental Involvement.

\begin{tabular}{|c|c|c|c|c|c|}
\hline & \multicolumn{5}{|c|}{ Dependent variables: } \\
\hline & \multicolumn{2}{|c|}{ Mother } & \multicolumn{2}{|c|}{ Father } & \multirow[b]{2}{*}{$\mathrm{N}$} \\
\hline & Level & Distance & Level & Distance & \\
\hline Locus of control & $\begin{array}{c}0.153 \\
(0.000)\end{array}$ & $\begin{array}{c}0.088 \\
(0.000)\end{array}$ & $\begin{array}{c}0.159 \\
(0.000)\end{array}$ & $\begin{array}{r}-0.093 \\
(0.000)\end{array}$ & 2,274 \\
\hline Big Five: openness & $\begin{array}{c}0.150 \\
(0.000)\end{array}$ & $\begin{array}{c}-0.121 \\
(0.000)\end{array}$ & $\begin{array}{c}0.141 \\
(0.000)\end{array}$ & $\begin{array}{r}-0.077 \\
(0.000)\end{array}$ & 1,919 \\
\hline Big Five: conscientiousness & $\begin{array}{c}0.140 \\
(0.000)\end{array}$ & $\begin{array}{c}-0.114 \\
(0.000)\end{array}$ & $\begin{array}{c}0.116 \\
(0.000)\end{array}$ & $\begin{array}{c}-0.087 \\
(0.000)\end{array}$ & 1,915 \\
\hline Big Five: extraversion & $\begin{array}{c}0.165 \\
(0.000)\end{array}$ & $\begin{array}{r}-0.089 \\
(0.000)\end{array}$ & $\begin{array}{c}0.152 \\
(0.000)\end{array}$ & $\begin{array}{c}0.059 \\
(0.001)\end{array}$ & 1,918 \\
\hline Big Five: agreeableness & $\begin{array}{c}0.159 \\
(0.000)\end{array}$ & $\begin{array}{r}-0.089 \\
(0.000)\end{array}$ & $\begin{array}{c}0.172 \\
(0.000)\end{array}$ & $\begin{array}{c}-0.081 \\
(0.000)\end{array}$ & 1,926 \\
\hline Big Five: neuroticism & $\begin{array}{c}0.100 \\
(0.000)\end{array}$ & $\begin{array}{r}-0.105 \\
(0.000)\end{array}$ & $\begin{array}{c}0.077 \\
(0.000)\end{array}$ & $\begin{array}{r}-0.083 \\
(0.000)\end{array}$ & 1,924 \\
\hline Risk & $\begin{array}{c}-0.071 \\
(0.000)\end{array}$ & $\begin{array}{c}-0.095 \\
(0.000)\end{array}$ & $\begin{array}{c}-0.064 \\
(0.000)\end{array}$ & $\begin{array}{c}-0.078 \\
(0.000)\end{array}$ & 3,393 \\
\hline Trust & $\begin{array}{c}0.120 \\
(0.000)\end{array}$ & $\begin{array}{c}-0.063 \\
(0.001)\end{array}$ & $\begin{array}{c}0.124 \\
(0.000)\end{array}$ & $\begin{array}{r}-0.076 \\
(0.000)\end{array}$ & 2,119 \\
\hline
\end{tabular}

Notes: This table lists the coefficients of the LW involvement variables (constructed using the Lubotsky-Wittenberg method, hence the involvement variable differ over specifications) for mothers and fathers in regressions on different preference and attitude and personality measures. The control variables are the same as in the main specification, see Table 3. In Columns (1) and (3) the dependent variable is the child's level of the respective attitude. In Columns (2) and (4) the dependent is the distance in the attitude between the respective parent and the child. $p$-values in brackets, based on clustered standard errors.

Table A5. Domain-Specific Risk Attitudes: Level and Distance on Parental Involvement.

\begin{tabular}{|c|c|c|c|c|c|}
\hline & \multicolumn{5}{|c|}{ Dependent variables: } \\
\hline & \multicolumn{2}{|c|}{ Mother } & \multicolumn{2}{|c|}{ Father } & \multirow[b]{2}{*}{$\mathrm{N}$} \\
\hline & Level & Distance & Level & Distance & \\
\hline Risk driving & $\begin{array}{r}-0.065 \\
(0.007)\end{array}$ & $\begin{array}{c}-0.051 \\
(0.040)\end{array}$ & $\begin{array}{r}-0.070 \\
(0.013)\end{array}$ & $\begin{array}{c}-0.021 \\
(0.462)\end{array}$ & 2,005 \\
\hline Risk financial & $\begin{array}{r}-0.049 \\
(0.041)\end{array}$ & $\begin{array}{r}-0.061 \\
(0.017)\end{array}$ & $\begin{array}{c}-0.039 \\
(0.159)\end{array}$ & $\begin{array}{c}-0.027 \\
(0.318)\end{array}$ & 2,104 \\
\hline Risk sport & $\begin{array}{r}-0.030 \\
(0.214)\end{array}$ & $\begin{array}{c}-0.031 \\
(0.196)\end{array}$ & $\begin{array}{c}-0.027 \\
(0.332)\end{array}$ & $\begin{array}{c}-0.011 \\
(0.712)\end{array}$ & 2,210 \\
\hline Risk occupation & $\begin{array}{r}-0.056 \\
(0.038)\end{array}$ & $\begin{array}{c}-0.031 \\
(0.218)\end{array}$ & $\begin{array}{r}-0.080 \\
(0.009)\end{array}$ & $\begin{array}{c}0.019 \\
(0.529)\end{array}$ & 2,031 \\
\hline Risk health & $\begin{array}{r}-0.048 \\
(0.043)\end{array}$ & $\begin{array}{r}-0.046 \\
(0.050)\end{array}$ & $\begin{array}{r}-0.077 \\
(\mathbf{0 . 0 0 5})\end{array}$ & $\begin{array}{c}0.025 \\
(0.377)\end{array}$ & 2,220 \\
\hline
\end{tabular}

Notes: This table lists the OLS coefficients of the PCA involvement variables for mothers and fathers in regressions on different preference and attitude and personality measures. The control variables are the same as in the main specification, see Table 3. In Columns (1) and (3) the dependent variable is the child's level of the respective attitude. In Columns (2) and (4) the dependent is the distance in the attitude between the respective parent and the child. $p$-values in brackets. 
CPB Netherlands Bureau for Economic Policy Analysis, Netherlands

University of Bonn, Germany, IZA Institute of Laobr Economics, Bonn, Germany, Maastricht University, Netherlands, DIW, Germany, CESifo, Germany

Maastricht University, CEPR, CESifo, IZA, DIA \& SOFI, Sweden

Additional Supporting Information may be found in the online version of this article:

\section{Online Appendix \\ Replication Package}

\section{References}

Alan, S., Baydar, N., Boneva, T., Crossley, T.F. and Ertac, S. (2017). 'Transmission of risk preferences from mothers to daughters', Journal of Economic Behavior \& Organization, vol. 134, pp. 60-77.

Alesina, A. and La Ferrara, E. (2002). 'Who trusts others?', Journal of Public Economics, vol. 85(2), pp. $207-34$.

Almlund, M., Duckworth, A.L., Heckman, J. and Kautz, T. (2011). 'Personality psychology and economics', Handbook of the Economics of Education, vol. 4(1), pp. 1-181.

Anger, S. (2012). 'The intergenerational transmission of cognitive and non-cognitive skills during adolescence and young adulthood', SOEPpapers on Multidisciplinary Panel Data Research, No. 473.

Aunola, K., Stattin, H. and Nurmi, J.E. (2000). 'Parenting styles and adolescents' achievement strategies', Journal of Adolescence, vol. 23(2), pp. 205-22.

Baker, M. and Milligan, K. (2016). 'Boy-girl differences in parental time investments: evidence from three countries', Journal of Human Capital, vol. 10(4), pp. 399-441.

Becker, A., Deckers, T., Dohmen, T., Falk, A. and Kosse, F. (2012). 'The relationship between economic preferences and psychological personality measures', Annual Review of Economics, vol. 4(1), pp. 453-78.

Bisin, A. and Verdier, T. (2001). 'The economics of cultural transmission and the dynamics of preferences.', Journal of Economic Theory, vol. 97(2), p. 298-319.

Björklund, A., Lindahl, L. and Lindquist, M. (2010). 'What more than parental income, education and occupation? An exploration of what Swedish siblings get from their parents', BE Journal of Economic Analysis \& Policy, vol. 10(1), pp. 102.

Björklund, A. and Salvanes, K.G. (2011). 'Education and family background: mechanisms and policies', Handbook of the Economics of Education, vol. 3, pp. 201-47.

Black, S.E. and Devereux, P.J. (2011). 'Recent developments in intergenerational mobility', in (O. Ashenfelter and D. Card, eds.), Handbook of Labor Economics, vol. 4, pp. 1487-541, Elsevier.

Bowles, S. and Gintis, H. (2002). 'The inheritance of inequality', Journal of Economic Perspectives, vol. 16(3), p. 3.

Bowles, S., Gintis, H. and Osborne, M. (2001). 'The determinants of earnings: a behavioral approach', Journal of Economic Literature, vol. 39(4), pp. 1137-76.

Brenøe, A.A. and Epper, T. (2019). 'Parenting values moderate the intergenerational transmission of time preferences', University of Zurich, Department of Economics, Working Paper No. 333.

Cesarini, D., Dawes, C., Johannesson, M., Lichtenstein, P. and Wallace, B. (2009). 'Genetic variation in preferences for giving and risk taking', Quarterly Journal of Economics, vol. 124(2), pp. 809-42.

Cunha, F. and Heckman, J. (2007). 'The technology of skill formation', American Economic Review, vol. 97(2), pp. $31-47$.

Doepke, M. and Zilibotti, F. (2008). 'Occupational choice and the spirit of capitalism', Quarterly Journal of Economics, vol. 123(2), pp. 747-93.

Doepke, M. and Zilibotti, F. (2017). 'Parenting with style: altruism and paternalism in intergenerational preference transmission', Econometrica, vol. 85(5), pp. 1331-71.

Dohmen, T., Falk, A., Huffman, D. and Sunde, U. (2012). 'The intergenerational transmission of risk and trust attitudes', Review of Economic Studies, vol. 79(2), pp. 645-77.

Dohmen, T., Falk, A., Huffman, D., Sunde, U., Schupp, J. and Wagner, G.G. (2011). 'Individual risk attitudes: measurement, determinants, and behavioral consequences', Journal of the European Economic Association, vol. 9(3), pp. 522-50.

Duncan, G., Kalil, A., Mayer, S.E., Tepper, R. and Payne, M.R. (2005). 'The apple does not fall far from the tree', in (S. Bowles, H. Gintis and M. Osborne Groves, eds.), Unequal Chances: Family Background and Economic Success, pp. 23-79, New York: Russell Sage Foundation.

Falk, A., Kosse, F., Pinger, P., Deckers, T. and Schildberg-Hörisch, H. (2021). 'Socio-economic status and inequalities in children's IQ and economic preferences', Journal of Political Economy, forthcoming.

Fehr, E., Fischbacher, U., Von Rosenbladt, B., Schupp, J. and Wagner, G.G. (2002). 'A nation-wide laboratory: examining trust and trustworthiness by integrating behavioral experiments into representative survey', Schmollers Jahrbuch, vol. 122, pp. 519-42.

(C) 2021 Royal Economic Society. 
Gerlitz, J.Y. and Schupp, J. (2005). 'Zur Erhebung der Big-Five-basierten persoenlichkeitsmerkmale im SOEP', DIW Research Notes, no. 4, DIW/SOEP Berlin.

Grönqvist, E., Öckert, B. and Vlachos, J. (2017). 'The intergenerational transmission of cognitive and noncognitive abilities', Journal of Human Resources, vol. 52(4), pp. 887-918.

Guiso, L., Sapienza, P. and Zingales, L. (2008). 'Social capital as good culture', Journal of the European Economic Association, vol. 6(2-3), pp. 295-320.

Heckman, J., Pinto, R. and Savelyev, P. (2013). 'Understanding the mechanisms through which an influential early childhood program boosted adult outcomes', American Economic Review, vol. 103(6), pp. 2052-86.

Heckman, J.J. (2005). '1. The scientific model of causality', Sociological Methodology, vol. 35(1), pp. 1-97.

Heckman, J.J., Holland, M.L., Makino, K.K., Pinto, R. and Rosales-Rueda, M. (2017). 'An analysis of the Memphis nurse-family partnership program', NBER Working Paper No. 23610, National Bureau of Economic Research, Cambridge, MA.

Holmlund, H., Lindahl, M. and Plug, E. (2011). 'The causal effect of parents' schooling on children's schooling: a comparison of estimation methods', Journal of Economic Literature, vol. 49(3), pp. 615-51.

Josef, A.K., Richter, D., Samanez-Larkin, G.R., Wagner, G.G., Hertwig, R. and Mata, R. (2016). 'Stability and change in risk-taking propensity across the adult life span', Journal of Personality and Social Psychology, vol. 111(3), pp. 430-50.

Kosse, F., Deckers, T., Pinger, P., Schildberg-Hörisch, H. and Falk, A. (2020). 'The formation of prosociality: causal evidence on the role of social environment', Journal of Political Economy, vol. 128(2), pp. 434-67.

Lindahl, M., Lundberg, E., Palme, M. and Simeonova, E. (2016). 'Parental influences on health and longevity: lessons from a large sample of adoptees', NBER Working Paper No. 21946, National Bureau of Economic Research, Cambridge, MA.

Loehlin, J.C. (2005). 'Resemblance in personality and attitudes between parents and their children', in (S. Bowles, H. Gintis and M. Groves, eds.), Unequal Chances: Family Background and Economic Success, pp. 192-207, New York: Russell Sage Foundation.

Lubotsky, D. and Wittenberg, M. (2006). 'Interpretation of regressions with multiple proxies', Review of Economics and Statistics, vol. 88(3), pp. 549-62.

Oster, E. (2019). 'Unobservable selection and coefficient stability: theory and evidence', Journal of Business \& Economic Statistics, vol. 37(2), pp. 187-204.

Patacchini, E. and Zenou, Y. (2016). 'Social networks and parental behavior in the intergenerational transmission of religion', Quantitative Economics, vol. 7(3), pp. 969-95.

Richter, D., Metzing, M., Weinhardt, M. and Schupp, J. (2013). 'SOEP scales manual', SOEP Survey Papers no. 138, DIW/SOEP, Berlin.

Schupp, J. and Wagner, G.G. (2002). 'Maintenance of and innovation in long-term panel studies: the case of the German Socio-Economic Panel (GSOEP)', Allgemeines Statistisches Archiv/Journal of the German Statistical Society, vol. 86(2), pp. 163-75.

Specht, J., Egloff, B. and Schmukle, S.C. (2013). 'Everything under control? The effects of age, gender, and education on trajectories of perceived control in a nationally representative German sample', Developmental Psychology, vol. 49(2), p. 353.

Wagner, G.G., Frick, J.R. and Schupp, J. (2007). 'The German socio-economic panel study (SOEP)—scope, evolution and enhancements', Schmollers Jahrbuch, vol. 127(1), pp. 139-69.

Wagner, G.G., Göbel, J., Krause, P., Pischner, R. and Sieber, I. (2008). 'Das Sozio-oekonomische panel (SOEP): Multidisziplinäres Haushaltspanel und Kohortenstudie für Deutschland-Eine Einführung (für neue Datennutzer) mit einem Ausblick (für erfahrene Anwender)', AStA Wirtschafts-und Sozialstatistisches Archiv, vol. 2(4), pp. 301-28.

Weinhardt, M. and Schupp, J. (2011). 'Multi-Itemskalen im SOEP Jugendfragebogen', SOEP Data Documentation no. 60, DIW/SOEP Berlin. 